\title{
Competitive actions of companies whose revenue relies on open source software
}

by

Glen McInnis

A thesis submitted to the Faculty of Graduate Studies and Research in partial fulfillment of the requirements for the degree of Master of Applied Science in Technology Innovation Management

Department of Systems and Computer Engineering Carleton University

Ottawa, Canada K1S 5B6

November 2008

CC Copyright 2008 Glen Mclnnis 


$\begin{array}{ll}\begin{array}{l}\text { Library and } \\ \text { Archives Canada }\end{array} & \begin{array}{l}\text { Bibliothèque et } \\ \text { Archives Canada }\end{array} \\ \begin{array}{l}\text { Published Heritage } \\ \text { Branch }\end{array} & \begin{array}{l}\text { Direction du } \\ \text { Patrimoine de l'édition }\end{array} \\ \begin{array}{l}\text { 395 Wellington Street } \\ \text { Ottawa ON K1A 0N4 } \\ \text { Canada }\end{array} & \begin{array}{l}\text { 395, rue Wellington } \\ \text { Ottawa ON K1A 0N4 } \\ \text { Canada }\end{array}\end{array}$

Your file Votre référence ISBN: 978-0-494-47518-8 Ourfile Notre référence ISBN: 978-0-494-47518-8

NOTICE:

The author has granted a nonexclusive license allowing Library and Archives Canada to reproduce, publish, archive, preserve, conserve, communicate to the public by telecommunication or on the Internet, loan, distribute and sell theses worldwide, for commercial or noncommercial purposes, in microform, paper, electronic and/or any other formats.

The author retains copyright ownership and moral rights in this thesis. Neither the thesis nor substantial extracts from it may be printed or otherwise reproduced without the author's permission.
AVIS:

L'auteur a accordé une licence non exclusive permettant à la Bibliothèque et Archives Canada de reproduire, publier, archiver, sauvegarder, conserver, transmettre au public par télécommunication ou par l'Internet, prêter, distribuer et vendre des thèses partout dans le monde, à des fins commerciales ou autres, sur support microforme, papier, électronique et/ou autres formats.

L'auteur conserve la propriété du droit d'auteur et des droits moraux qui protège cette thèse. $\mathrm{Ni}$ la thèse ni des extraits substantiels de celle-ci ne doivent être imprimés ou autrement reproduits sans son autorisation.
In compliance with the Canadian Privacy Act some supporting forms may have been removed from this thesis.

While these forms may be included in the document page count, their removal does not represent any loss of content from the thesis.
Conformément à la loi canadienne sur la protection de la vie privée, quelques formulaires secondaires ont été enlevés de cette thèse.

Bien que ces formulaires aient inclus dans la pagination, il n'y aura aucun contenu manquant.

\section{Canada}


The undersigned hereby recommend to the Faculty of Graduate Studies and Research acceptance of the thesis

\title{
Competitive actions of companies whose revenue relies on open source software
}

\author{
submitted by \\ Glen Mclnnis \\ In partial fulfillment to the requirements for the degree of Master of Applied \\ Science in Technology Innovation Management
}

Victor Aitken, Department Chair

A.J. Bailetti, Thesis Supervisor

Carleton University

November 2008 


\section{ABSTRACT}

This exploratory research examines the competitive actions enabled by open source projects. Using Walter Ferrier's (2001) description of competitive actions, data on 77 companies is used to: (i) identify and describe the competitive actions that are carried out by companies whose revenues rely on open source projects; (ii) identify those actions that have not been reported in the literature; and (iii) make observations that may be useful to top management teams of companies.

Factor analysis was used to examine 39,537 news releases posted in the websites of 77 companies. Of the 14 factors identified, 10 or $71 \%$ correspond to competitive actions that are not commonly examined in the literature. 


\section{TABLE OF CONTENTS}

ABSTRACT. iii

LIST OF TABLES

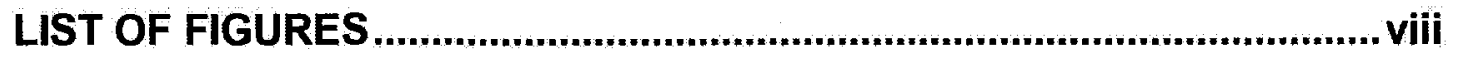

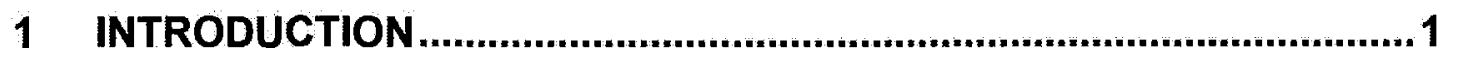

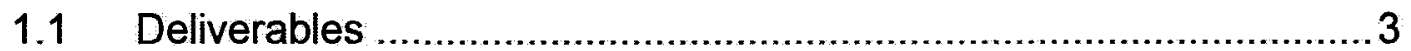

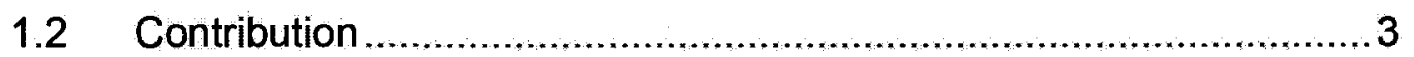

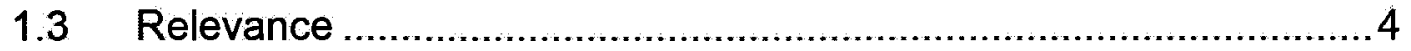

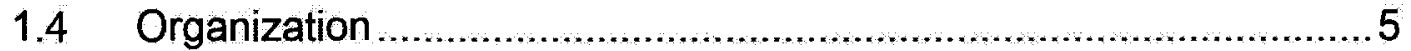

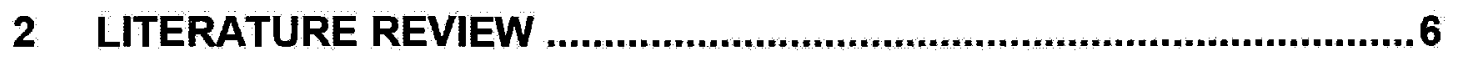

2.1 Review of open source competitive dynamics literature ...................6

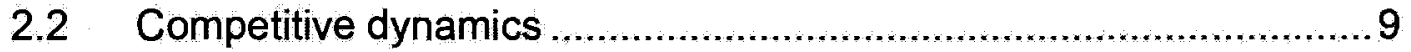

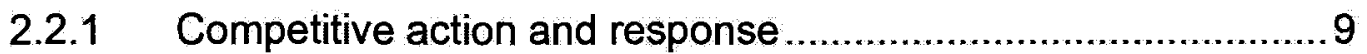

2.2.2 First mover advantage ................................................13

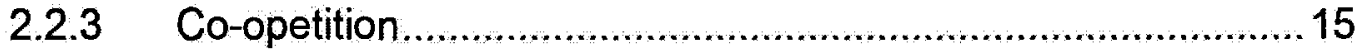

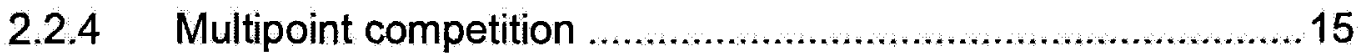

2.3 Lessons learned from the literature review..................................16

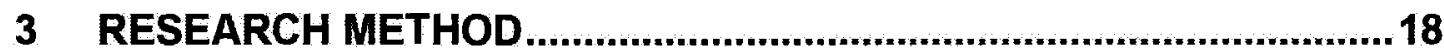

3.1 Unit of analysis, study period and sample selection criteria ...........18

3.2 Sample of open source companies ........................................... 19

3.3 Keywords describing competitive actions ....................................19

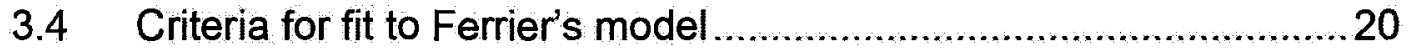

3.5 Keyword frequencies in the websites of OS companies ................. 21

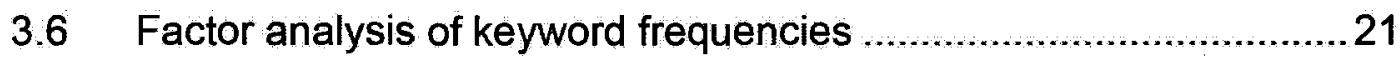

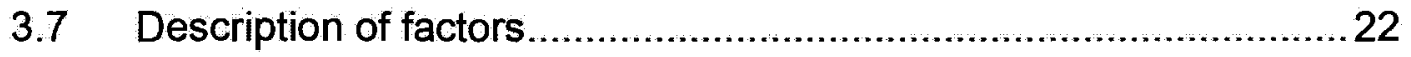

3.8 Observations useful to top management of software companies ....22 


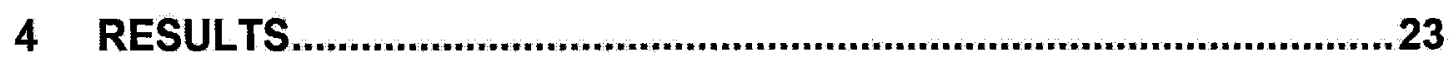

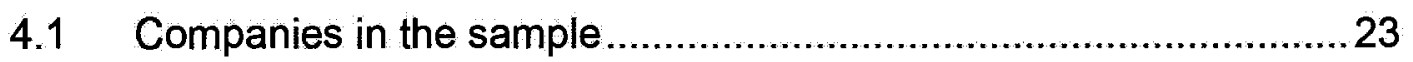

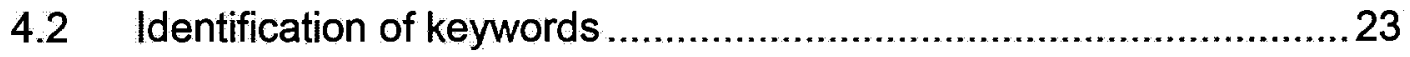

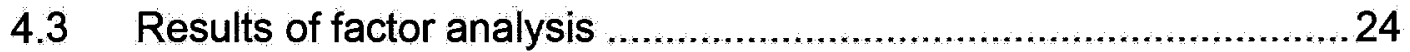

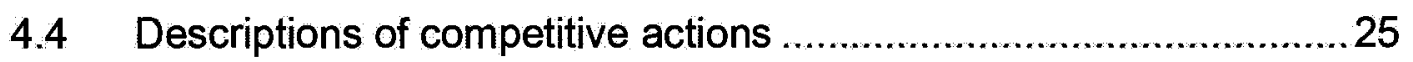

4.4.1 Factor 1: Expand value ...................................................25

4.4.2 Factor 2: Attract senior executives ......................................28

4.4.3 Factor 3: Gain insight into open source..............................30

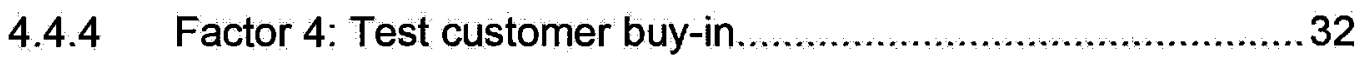

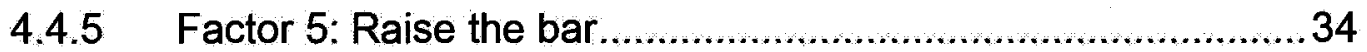

4.4.6 Factor 6: Provide customers with ability ..................................36

4.4.7 Factor 7: Release dual license...........................................38

4.4.8 Factor 8: Attract open source investors................................40

4.4.9 Factor 9: Enable end-user integration ...................................41

4.4.10 Factor 10: Provide support................................................43

4.4.11 Factor 11: Allow users to test solutions..................................45

4.4.12 Factor 12: Partner with trusted parties ................................46

4.4.13 Factor 13: Provide local support...........................................47

4.4.14 Factor 14: Reduce the cost of ownership...............................49

5 DISCUSSION OF RESULTS ..........................................................51

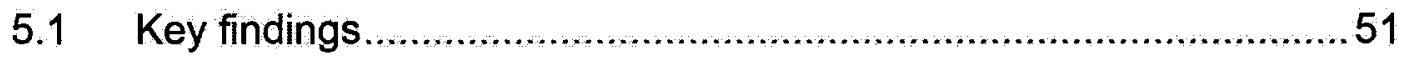

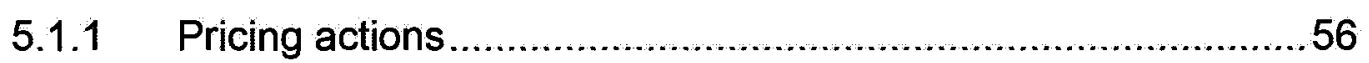

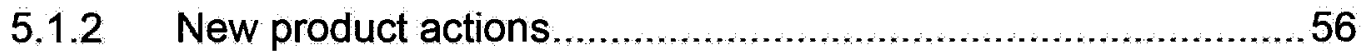

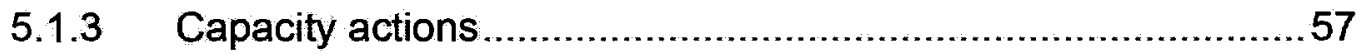

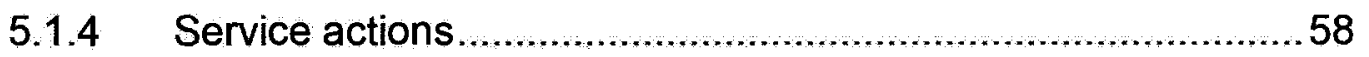

5.1.5 New actions identified in results of factor analysis ..................59

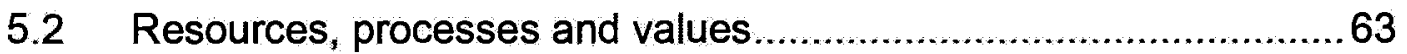

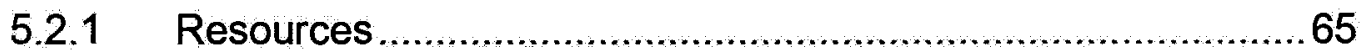




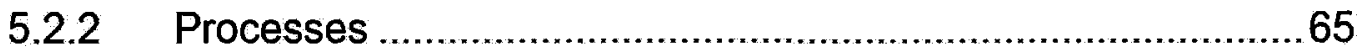

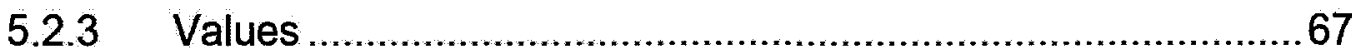

5.3 Suggestions for executives that compete with open source ............68

5.4 Suggestions for executives of open source companies.................69

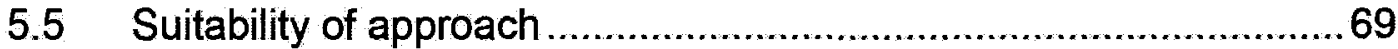

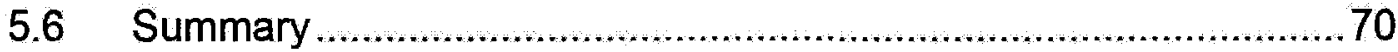

6 CONCLUSIONS, LIMITATIONS, AND FUTURE RESEARCH...............72

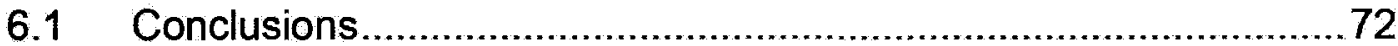

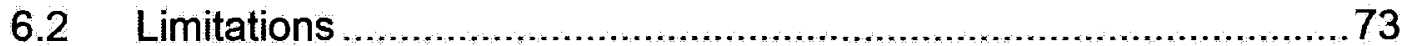

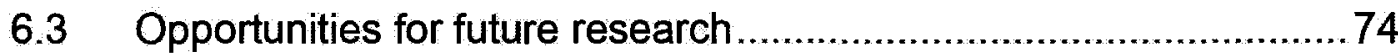

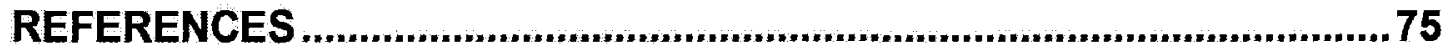

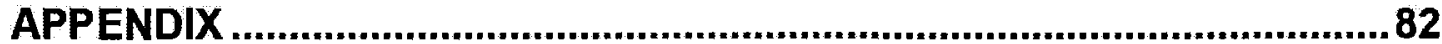

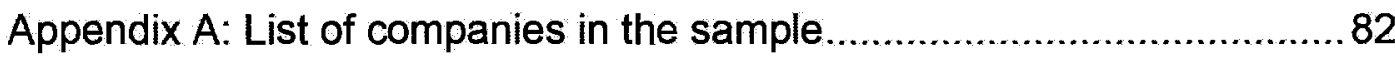

Appendix B: List of companies used to identify keywords.........................84

Appendix C: List of keywords used to examine news releases..................85

Appendix D: Factors that resulted from analysis of news releases ............86 


\section{LIST OF TABLES}

Table 1: Open source competitive actions extracted from the literature .............. 7

Table 2: Definitions of Ferrier's categories of competitive actions .................... 10

Table 3: Research utilizing Ferrier's categorization of competitive actions........ 10

Table 4: Contribution of new insights for Ferrier's categories .........................52

Table 5: Open source competitive actions and related factors ......................... 52

Table 6: RPV requirements to support open source competitive actions ...........64 


\section{LIST OF FIGURES}

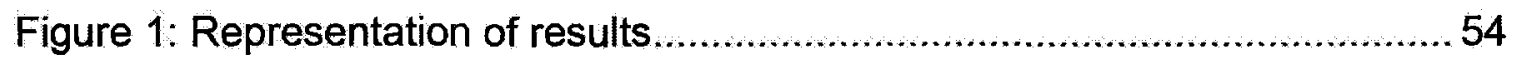




\section{INTRODUCTION}

This research uses 39,537 news releases obtained from the public websites of 77 companies to identify competitive actions enabled by open source projects. These companies rely on open source projects for their revenue. This research identifies how competitive actions enabled by open source projects map to the six categories defined by Ferrier (2001).

Open source software (OSS) has attracted significant investor attention in recent years. Venture capitalists have invested millions of dollars in open source companies such as Alfresco, GroundWork and GreenPlum (Aslett, 2007). The first quarter of 2008 saw record investment in open source companies (Dean, 2008). Large, well known companies have legitimized the use of OSS for competitive purposes. Linux, perhaps the most successful OSS project, has generated more than $\$ 1$ billion in annual revenues for both IBM and HP (Alam, 2006).

Several studies are available on the ways companies make money from open source projects (Raymond, 1999a; Koenig, 2004; Valimaki, 2003; Dahlander, 2004; Lerner \& Tirole, 2000; Pal \& Madanmohan, 2002) and the different ways companies use OSS to implement their strategies (Raymond, 1999a; Bonaccorsi \& Rossi, 2003; Henkel, 2003; West \& Gallagher, 2004). 
The open source literature covers pricing, open source platforms, hybrid strategies, licensing models and resource allocation to open source projects (von Krogh \& von Hippel, 2006); however this researcher's examination of the literature did not reveal a classification of the competitive actions carried out by open source companies.

This thesis answers two research questions:

- What competitive actions are enabled by open source projects?

- Are the competitive actions enabled by open source projects consistent with previous classifications of competitive actions?

For the purpose of this research, an OSS project refers to a project used to develop and release software under an open source license (von Krogh \& von Hippel, 2006). A competitive action is defined by Ferrier and Lee (2002) as an externally directed, specific, and observable competitive move initiated by a company to enhance its relative competitive position. Competitive strategy is defined as the ordered pattern of repeatable competitive actions carried out in a strategic time (Ferrier, 2001). OSS companies are defined as companies who rely on open source projects for their revenue. OSS competitive actions are defined as a competitive move initiated by an OSS company. 


\subsection{Deliverables}

This research has four deliverables:

1. A database of open source companies with publicly available news releases

2. Results of a factor analysis that extracts competitive actions from news releases

3. A comparison of competitive actions described by the factors to the actions identified in the open source literature and Ferrier's (2001) categorization of competitive actions

4. Observations for company executives

\subsection{Contribution}

This research makes at least four contributions.

First, the research provides a process to conduct inductive research and expand an existing classification through the use of publicly available content.

The second contribution of this research is to modify Ferrier's (2001) categorization of competitive actions to include the competitive actions of open source companies. 
The third contribution of this research is the identification of competitive actions of open source companies that do not fit Ferrier's categorization of competitive actions (Ferrier, 2001).

The fourth contribution of this research is to identify the resources, processes and values required by open source companies to deploy the competitive actions.

\subsection{Relevance}

There are at least three groups that will be interested in this research. First, researchers that carry out inductive research will be interested in the generalized process that has been used to evolve an existing categorization using publicly available information.

Top management teams of companies that use OSS and top management teams of companies who compete with these may also be interested in this research. This research will provide them with the information required to better plan and carry out competitive attacks using OSS as well as defend from these attacks. 
The third group that may be interested in this research is comprised of the entrepreneurs who wish to create new businesses anchored around OSS. Observations from this research can be incorporated into their business plans.

\subsection{Organization}

This thesis is organized into six chapters. Chapter 1 is the introduction. Chapter 2 reviews the relevant literature. Chapter 3 presents the method used to undertake this research. Chapter 4 presents the results. Chapter 5 discusses the results. Finally, Chapter 6 provides the conclusions, describes the limitations of the study, and identifies opportunities for future research. 


\section{LITERATURE REVIEW}

This chapter is organized into three sections. The first section reviews the literature on open source competitive dynamics as defined by von Krogh and von Hippel (2006). The second section reviews the literature on competitive dynamics, including competitive action and response. The third section provides the lessons learned from the literature.

\subsection{Review of open source competitive dynamics literature}

Open source software opens a broader context for technological innovation (Grand et al., 2005). The introduction of an open source product, priced at zero, introduces a number of issues for competition. These issues include (von Krogh \& von Hippel, 2006):

1. When directly competing, how do companies seeking to sell a product compete with free?

2. Under what conditions does co-opetition or full cooperation with open source projects make sense?

Table 1 identifies the six competitive actions enabled by OSS projects which were extracted from the open source literature. 
Table 1: Open source competitive actions extracted from the literature

\begin{tabular}{|l|l|}
\hline Reference & Action \\
\hline Bonaccorsi et al., 2006 & $\begin{array}{l}\text { Price software at zero and charge for additional } \\
\text { services or support }\end{array}$ \\
\hline Mustonen, 2005 & $\begin{array}{l}\text { Support open source projects that commoditize a } \\
\text { competitor's valuable resource }\end{array}$ \\
\hline Bonaccorsi et al., 2006 & $\begin{array}{l}\text { Assemble new programs from freely available open } \\
\text { source components }\end{array}$ \\
\hline Bonaccorsi et al., 2006 & $\begin{array}{l}\text { Offer dual license options for software, both open } \\
\text { source and commercial }\end{array}$ \\
\hline Economides \& Katsamakas, 2006 & $\begin{array}{l}\text { Offer a wider variety of applications (than proprietary } \\
\text { competitors) }\end{array}$ \\
\hline Economides \& Katsamakas, 2006 & $\begin{array}{l}\text { Create proprietary applications on-top of an open } \\
\text { source platform }\end{array}$ \\
\hline
\end{tabular}

\section{Competition for programmers}

The larger the market is compared to the population of potential programmers, the proprietary monopolist hires a greater share of the population, reducing the population of open source programmers (Mustonen, 2003).

\section{Competition for consumers}

When the cost of implementation is sufficiently low, some consumers will choose to use the open source product instead of the proprietary application. This forces the proprietary company to consider the open source alternative when pricing their product (Mustonen, 2003). Casadesus-Masanell and Ghemawat (2006) demonstrate that a proprietary, closed source company can survive when facing competition from an open source alternative. The strategic decision-making capabilities of the proprietary company allow them to make pricing decisions that negate the zero-price switching incentive of the open source competitor; however 
given a general bias to open source and the absence of incumbent advantages the only way for commercial software to control the market is to engage in massive research and development (Bonaccorsi and Rossi, 2003).

\section{Value, network effects and platforms}

Bonaccorsi and Rossi (2003) conclude that the diffusion of open source is influenced by its perceived intrinsic value, the negative externality effect coming from the dominating standard, the positive network externality effect coming from access to the community of open source programmers, and the competitive reactions of the incumbent proprietary companies.

Mustonen (2005) reasons that a company will support an open source project when that project complements their existing products, reduces the value of a competitor's product, or support of that project will create compatibilities in products that will demonstrate network effects.

In a study of proprietary and open source technology platforms, Economides and Katsamakas (2006) found that when proprietary applications are based on an open source platform, the application segment of the market can be more profitable than the total profits of a completely proprietary industry. However; they also found that a vertically integrated proprietary platform and application is 
more profitable than either the open source based platform with proprietary applications or the proprietary platform with disintegrated applications.

If the proprietary competitor does not respond and the size of the community required to create a positive network externality was negligible, then open source dominates the market. When negative network externalities do not exist, the proprietary solution still retains $38 \%$ of the market (Bonaccorsi and Rossi, 2003). Bonaccorsi and Rossi conclude that without a perceived intrinsic value, open source will not replace a proprietary standard.

\subsection{Competitive dynamics}

\subsubsection{Competitive action and response}

A competitive attack is defined as an ordered, uninterrupted sequence of repeatable competitive action events. A competitive action event is an externally directed, specific and observable competitive move initiated by a company to enhance its competitive position (Ferrier, 2001).

Ferrier (2001) classified action events into six groups: (i) pricing actions; (ii) marketing actions; (iii) new product actions; (iv) capacity actions; (v) service actions; and (vi) signaling actions. Ferrier defines these categories in his previous work (Ferrier, Smith, Grimm, 1999). This categorization evolved from 
previous research; namely Ferrier et al. (1999); and Young et al (1996). The 1996 iteration of this categorization included only pricing, new product and marketing actions. The 1999 study also included legal as an action category, but was removed from the categorization in later studies. Table 2 presents the keywords and definitions used by Ferrier (2001).

Table 2: Definitions of Ferrier's categories of competitive actions

\begin{tabular}{|l|l|l|}
\hline Action Category & Definition & Keywords \\
\hline Pricing & $\begin{array}{l}\text { Increasing, or lowering the price of a } \\
\text { product or service sold to a customer. } \\
\text { Offering a discount or rebate on the } \\
\text { purchase of a product. }\end{array}$ & price, rate, rebate, discount \\
\hline Marketing & $\begin{array}{l}\text { The creation and distribution of } \\
\text { advertisements or promotions as part of } \\
\text { a campaign. }\end{array}$ & $\begin{array}{l}\text { ads, spots, promote, distribute, } \\
\text { campaign }\end{array}$ \\
\hline Product & $\begin{array}{l}\text { The introduction, launch, roll-out or } \\
\text { unveiling of a product. }\end{array}$ & $\begin{array}{l}\text { introduce, launch, unveil, rolls } \\
\text { out }\end{array}$ \\
\hline Capacity & $\begin{array}{l}\text { The increase of manufacturing/creation } \\
\text { or service capacity or output. }\end{array}$ & $\begin{array}{l}\text { raises, boosts, increases [with } \\
\text { capacity or output] }\end{array}$ \\
\hline Service & $\begin{array}{l}\text { The introduction, launch, roll-out or } \\
\text { unveiling of a service. }\end{array}$ & $\begin{array}{l}\text { service, warrantee, guarantee, } \\
\text { financing }\end{array}$ \\
\hline Signaling & $\begin{array}{l}\text { Open statement of a company } \\
\text { promising or describing an upcoming (or } \\
\text { current) action or goal. }\end{array}$ & $\begin{array}{l}\text { vows, promises, says, seeks, } \\
\text { aims }\end{array}$ \\
\hline
\end{tabular}

Subsequent researchers have made use of this categorization. Located through references to Ferrier (2001) and Ferrier et al. (1999) those researchers and any modifications made to the categorization are shown in Table 3.

Table 3: Research utilizing Ferrier's categorization of competitive actions

\begin{tabular}{|l|l|}
\hline Researcher & Modifications \\
\hline Ferrier \& Lee, 2002 & None \\
\hline Ferrier et al., 2002 & None \\
\hline
\end{tabular}




\begin{tabular}{|l|l|}
\hline Ferrier \& Lyon, 2004 & None \\
\hline Basdeo et al., 2006 & None \\
\hline Williams, 2007 & None \\
\hline Nadkarni \& Narayanan, 2007 & None \\
\hline Derfus et al., 2008 & Removed signaling, introduced Geographic \\
\hline Boyd \& Bresser, 2008 & $\begin{array}{l}\text { Added range, format, geographic, direct } \\
\text { channels, mergers and acquisitions, and legal }\end{array}$ \\
\hline
\end{tabular}

While some recent researchers have extended Ferrier's (2001) classification, they have done so to account for specifics of the industry of study. Boyd and Bresser (2008) introduced new action categories that are required for their study of the retail industry. Those categories are: (i) range; (ii) format; (iii) geographic; (iv) direct channels; (v) merger and acquisition; and (vi) legal.

Ferrier considers the following properties of competitive attack: volume, duration, complexity and unpredictability. Attack volume is the total number of competitive actions that comprise each attack. Attack duration is the time elapsed from the beginning to the end of a sequence. Attack complexity is defined as the extent to which a sequence of actions is composed of many different types. Attack unpredictability is the extent to which a company's sequential order of competitive attacks is dissimilar from one attack period to the next.

Ferrier's research suggests that the characteristics of a company's top management team (TMT), past company performance, slack and a buffered industry influence the company's competitive actions. 
Ferrier (2001) found that a greater volume and duration of competitive attacks resulted in market share gain and that greater top management team heterogeneity was negatively related to attack duration. Market leaders are more likely to lose market share when a challenger initiates more competitive attacks, undertakes a broader attack, or is faster to act than the incumbent (Ferrier et al., 1999 and Ferrier \& Grimm, 2001).

Previous competitive strategies relied on the protection of intellectual property (Gans \& Stern, 2003). As the free revealing of intellectual property (IP) by open source runs counter to previous thinking on competition, Ferrier's (2001) categorization may not account for all the actions of a company whose revenue relies on open source projects.

Charitou and Markides (2003) offer four possibilities for companies to respond to a disruptive innovation: (i) managers believe the new innovation will not replace current offerings and focus on their traditional offerings; (ii) the company counters by introducing a disruption of their own; (iii) the company markets both the traditional and new offering; and (iv) the company acquiesces to the new paradigm. 


\subsubsection{First mover advantage}

The concept of first mover advantage refers to the benefits gained from pioneering efforts such as the introduction of a new product, entry into a new market, or the implementation of a new process (Lieberman \& Montgomery, 1988). However, first moves come with inherent risk (Boulding \& Christen, 2001). Learning from the first mover, followers can have advantages of learning from the mistakes of the first mover by adopting faster processes and lowering costs.

The main factors of the first mover advantage are: (i) sustainability; (ii) internal contingencies; and (iii) external contingencies (Ketchen et al., 2004). First mover advantages can arise from: (i) learning curves; (ii) control of scarce resources; or (iii) the creation of buyer switching costs. General findings indicate that first mover advantages erode over time as competitors learn to imitate or improve on the initial offering.

When studying internal and external contingencies it has been found that (Ketchen et al., 2004):

1. A direct sales force can lead to faster entry; through customer education and efficient targeting of new products

2. In hostile environments first movers are best off charging higher prices and limiting the new product line 
3. Government rules and regulations can negate first mover advantage

4. Service companies are less able to capitalize on first-move as services are often easily replicated

5. When product quality is the most important attribute to the customer, imitators were better able to use new, improved technology to gain position over the first mover

Dahlander (2005) suggests that open source allows companies to more easily reap first mover advantages and network externalities. Being the first company to develop a relationship with an open source project may provide the opportunity to influence the open source community, standards and directions the project takes (Cottrell and Sick, 2001). Contrary to traditional views, first movers need to orchestrate abundant external resources - the open source community.

Bonaccorsi and Rossi (2004) and Dahlander and Magnusson (2005) provide three approaches that companies can use to manage their relationship with an open source project: (i) symbiotic; (ii) commensalistic; and (iii) parasitic. Of the three approaches only the symbiotic approach offers a high chance of the open source company being able to exert a high level of influence on the project. Companies must respect the norms and values of the community, which include abiding by license restrictions. The onus is on the company to give something to 
the community. This may include attracting developers, devoting company staff to work in the project or selling development tasks to community members.

\subsubsection{Co-opetition}

Brandenburger and Nalebuff (1997) describe co-opetition as two companies engaged simultaneously in both competitive and cooperative actions with each other. Cooperation decreases when extensive benefits are gained by only one alliance member and a company will compete more when the alliance is not viewed as a key part of the company's strategy (Khanna et al., 2000; Das \& Tang, 2000).

\subsubsection{Multipoint competition}

Multipoint competition is concerned with competition of companies in two or more arenas. This may include multiple products, geographic regions or market segments.

Mutual forbearance is the ceding of control of one product or geographic market to a competitor in exchange for that competitor's acquiescence in another market (Ketchen et al., 2004). As multipoint contact increases, the level of competition decreases and profitability increases (Gimeno \& Woo, 1999). Gimeno (1999) also found that the relative strategic importance of a market to each company will affect decisions. When Company $\mathrm{A}$ has a greater interest in Market 1 than 
Company $\mathrm{B}$, but Company $\mathrm{B}$ has a greater interest in Market 2; they are less likely to engage in intense rivalry. Young et al. (2000) found that when companies relied on different resources, their competitive behavior becomes more aggressive.

When multipoint contact is low, a company will attempt to engage the competitor in multiple markets as a means to gather information. Also, it will enter multiple markets in order to appear as a credible threat. Therefore, when multipoint contact is low, entry into multiple markets will be fast. The rate of expansion decreases as more points of competition are created (Haveman \& Nonnemaker, 2000).

\subsection{Lessons learned from the literature review}

This section provides the lessons learned from the literature review.

1. Lack of research on how companies using OSS to compete with proprietary companies and each other. Literature is available on the equilibrium of headto-head competition between a proprietary and open source company, but not the particular methods they use to compete. Competition can be viewed in two contexts: (i) direct action and response; and (ii) contextual settings of multipoint competition and alliances. The competition literature stream is concerned with traditional product companies with closed IP. 
2. Six competitive actions carried out by open source companies were identified from the literature.

3. A review of the literature on open source revealed additional insights for three of Ferrier's categories of competitive actions: (i) pricing; (ii) new product; and (iii) capacity.

4. Ferrier's (2001) categorization does not fit all industry contexts.

5. Increased code modularity and option value of an open source code base increases incentive for developers to join, reduces free-riding and imposes price discipline on a proprietary competitor.

6. Characteristics of top management can affect ability to engage in effective competitive action. Top management heterogeneity reduces the volume and duration of competitive attacks; however the competitive dynamics literature does not consider top members of the open source project in this examination. 


\section{RESEARCH METHOD}

This chapter is organized into eight sections detailing the research method. The research method used follows the approach of Hicks, Libaers, Porter, Schoenack (2006) for the examination of company websites.

The following steps were undertaken in this research:

1. Specify unit of analysis, study period and sample selection criteria

2. Identify sample of companies who rely on open source projects for their revenue

3. Select keywords that describe the competitive actions of open source companies

4. Set criteria to decide whether or not results fit Ferrier's model

5. Determine keyword frequencies in the news releases of sample companies

6. Perform factor analysis of keyword frequencies

7. Describe the factors

8. Provide observations to top management

\subsection{Unit of analysis, study period and sample selection criteria}

The unit of analysis was a company who contributed to an open source project or uses an open source project as part of a product or service offering. The criteria for company selection were: 
- The company relied on an open source project for generation of revenue

- In 2008 , the company was operating and maintaining a public website that contained news releases

\subsection{Sample of open source companies}

A single inclusive database of companies whose revenue relies on OSS does not exist. Thus, a database of such companies was produced using information available online. For each company, the name of the company and the address of the company website were recorded in a database.

The two primary sources of information were www.opensourceexperts.com and the Canadian Companies Capabilities Directory of OS Companies (http://strategis.ic.gc.ca/epic/site/ict-tic.nsf/en/h it07356e.html) database maintained by Industry Canada. Further results where obtained by performing a search on Google for the terms "OS company", "OS company", and "OS services". Companies were investigated to determine their revenue relied on OSS.

\subsection{Keywords describing competitive actions}

Keyword analysis of websites can reveal competitive actions (Hicks et al., 2006). Published information about a company is useful in examining the company's strategic process (Ginsberg, 1988). The strategies of companies are revealed in 
the content of their websites (Hicks et al., 2006). Competitive strategy is comprised of competitive attacks (Ferrier, 2001).

Using a theoretically informed sample of the selected OS companies, the researcher began the process of keyword selection. Care was taken to ensure that the keywords selected not only described the actions of the companies, but also the literature on competitive actions and strategy.

The pages examined on websites were the news releases. The result of this step was a list of keywords that describe the competitive actions of OS companies.

\subsection{Criteria for fit to Ferrier's model}

To determine if resulting factors fit to Ferrier's model of competitive actions, the researcher made the following comparisons:

1. Keywords correlated to each factor were compared to the keywords selected by Ferrier (Ferrier, Smith, Grimm, 1999)

2. The intention of the keywords and definitions used by Ferrier (2001) were compared to the descriptions of factors developed by the researcher When these comparisons resulted in a match in keywords or intention, the factor was determined to fit with Ferrier's existing classification. 


\subsection{Keyword frequencies in the websites of OS companies}

To obtain the frequency of keyword occurrence on the websites of the identified companies, the Microsoft search engine was used (Hicks et al., 2006). For each of the keywords, a search was performed. The number of hits was recorded as well as the total number of news releases on the website. The frequency of each keyword was recorded to the database as the number of results divided by the number of news releases on the site.

This process was automated using a software application created by the researcher that made use of the Live Search API to automatically run and record results of the keyword searches. The result of this collection process is a matrix of company by term frequencies.

\subsection{Factor analysis of keyword frequencies}

The keyword frequency matrices produced in the previous step were examined using factor analysis. Darlington (2007) states that factor analysis seeks to discover if the observed variables can be explained largely or entirely in terms of a much smaller number of variables. The researcher sought to use factor analysis to arrive at the minimal set of competitive actions that explained the competitive strategies of the companies. The result of this analysis was a set of factors containing the keywords that provide the minimal explanation of the competitive actions of OS companies. 


\subsection{Description of factors}

The description of competitive actions was created using the factors identified in the previous step. For each factor, the associated keywords were listed and a description of the underlying competitive actions created using knowledge of the competitive dynamics and OS literature. For each category several samples of companies' news releases were included.

\subsection{Observations useful to top management of software companies}

To provide recommendations to top management of companies the researcher drew on his nine years of experience in the software industry, the developed descriptions of competitive actions and the identification of unique open source actions to inform managers what competitive actions are carried out by open source companies and where the focus of competition lies for open source companies. 


\section{RESULTS}

This chapter is organized into four sections. The first section summarizes the sample of companies and open source projects included in the sample. The second section presents the list of competitive keywords identified from the reading of the websites and presents the classification of those keywords. The third section presents the results of the factor analysis. The fourth section describes the factor results as competitive actions.

\subsection{Companies in the sample}

Appendix A provides a list of companies that rely on open source projects for their revenue. Of the 101 companies first identified, only 77 matched the selection criteria. This is the list found in Appendix A. A total of 24 companies were excluded from the sample because their websites did not contain news releases.

\subsection{Identification of keywords}

The keywords used to analyze the news releases of companies were developed from the initial sample of companies found in Appendix $B$. The reading of these news releases resulted in the list of keywords presented in Appendix $C$. 


\subsection{Results of factor analysis}

The factor analysis resulted in $\mathbf{5 5}$ multi-keyword factors. The 55 factors included 48 of the 55 keywords. Of those 55 factors, only the dominant 14 factors were retained. The criteria for retention of a factor were:

1. Factors required an eigenvalue greater than 1.0

2. Factors had two or more keywords with correlations greater than 0.40

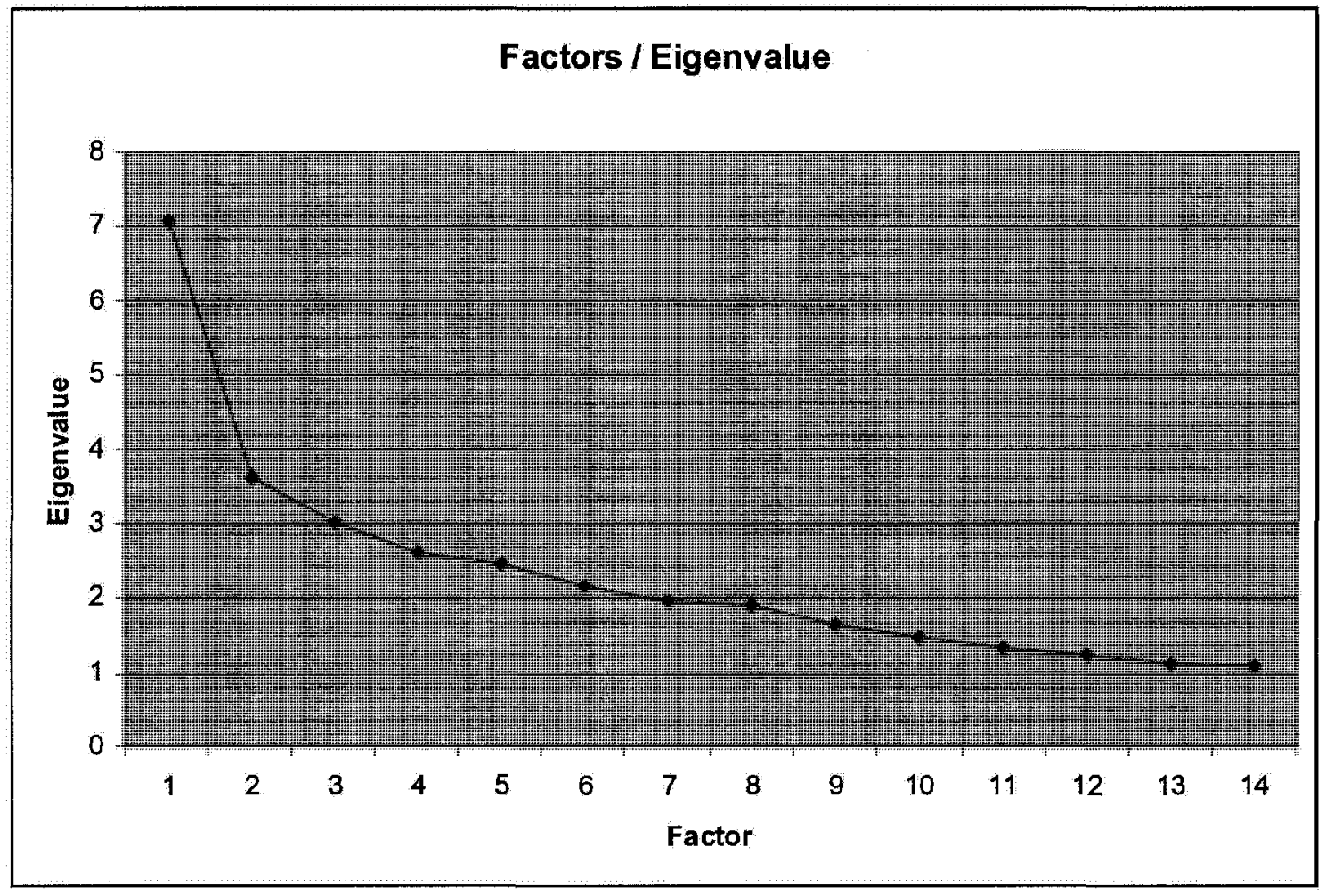

Appendix $D$ presents the factors with eigenvalues greater than 1.0 . 


\subsection{Descriptions of competitive actions}

The 14 retained factors are described in the following section. For each factor the following information is given: (i) the list of keywords; (ii) a description of the underlying competitive action(s); and (iii) excerpts from the news releases of sample company websites to further illustrate.

\subsubsection{Factor 1: Expand value}

This factor has a factor loading of 7.066 and accounts for $12.8 \%$ of the total variation in the data. Based on the included keywords, this factor has been titled "Expand value".

\section{Keywords}

The following keywords are correlated with factor 1 .

\begin{tabular}{|l|c|}
\hline Keyword & Correlation to factor \\
\hline adoption lead & 0.9768 \\
\hline global reach & 0.8937 \\
\hline expand adoption & 0.7340 \\
\hline Sponsor & 0.7331 \\
\hline join executive & 0.5777 \\
\hline adoption community & 0.5590 \\
\hline new alternative & 0.4891 \\
\hline
\end{tabular}




\begin{tabular}{|l|c|}
\hline partner program & 0.4245 \\
\hline
\end{tabular}

\section{Narrative}

Open source companies strongly demonstrate in their actions a drive to increase the value of their offerings. By sponsoring conferences and events; attracting a global network of partners; and supporting myriad technology platforms, open source companies aim to remove adoption barriers and increase the value of their product; particularly as the leading alternative to the competing proprietary offering.

\section{Example Text}

Customer adoption is being fueled by the flexibility customers gain through multiple deployment options (On-Site, On-Demand or Appliance-Based Solutions), the ubiquity of open source technologies on which SugarCRM is based (Linux, MySQL, Apache, PHP) and SugarCRM's support for multiple platforms (Microsoft Windows, Apple OS X, and LinuX) as well as database support for Oracle, Microsoft and MySQL.

Source: http://www.sugarcrm.com/crm/about/press-releases/200612181000 customers.html 
Project Zenoss: A New Alternative for Enterprise Systems Monitoring

Source: http://www.zenoss.com/news/archive/zenossnews.2007-06-

\section{$\underline{07.2849868567}$}

"The combination of BT's incredible reach in the UK market and SugarCRM's industry-leading CRM solutions makes this a perfect partnership for the UK market," said John Roberts, CEO of SugarCRM. "This alliance strengthens our global reach and further exhibits SugarCRM's momentum as a global provider of business applications."

Source: http://www.sugarcrm.com/crm/about/press-releases/20080422-bt.html

SugarCRM partner program benefits, which include special partner Japanese language pack access, resell rights to Sugar commercial versions, and fully localized sales and marketing tools.

With over 120 commercial customers in Japan and Asia, SugarCRM continues to increase its global presence.

Source: http://www.sugarcrm.com/crm/about/press-releases/carebrains.html 
SugarCRM Opens New Office in Atlanta and names David Gearhart Regional VP of Corporate Sales.

Former Retaligent Solutions, M-Factor and Epiphany Executive to Foster Customer, Partner and Community Relations in Southeastern United States SugarCRM Inc., the world's leading provider of commercial open source customer relationship management (CRM) software, today announced the opening of its new southeast office in Atlanta, GA. Based on growing customer and community demand in the southeast of the United States, SugarCRM is bringing on 11-year CRM veteran, David Gearhart, as regional vice president to foster close relationships between SugarCRM and its customers, partners and developer community east of the Mississippi.

Source: http://www.sugarcrm.com/crm/about/press-releases/AtlantaOffice

\subsubsection{Factor 2: Attract senior executives}

This factor has a factor loading of 3.620 and accounts for $6.5 \%$ of the total variation in the data. Based on the included keywords, this factor has been titled "Attract senior executives". 


\section{Keywords}

The following keywords are correlated with factor 2 .

\begin{tabular}{|l|c|}
\hline Keyword & Correlation to factor \\
\hline joint solution & 0.8003 \\
\hline strength management & 0.6588 \\
\hline join leaders & 0.5809 \\
\hline join executive & 0.5605 \\
\hline deliver more value & 0.5531 \\
\hline innovation & 0.4422 \\
\hline rapid development & 0.4367 \\
\hline development center & 0.4353 \\
\hline
\end{tabular}

\section{Narrative}

Open source companies attract senior executives who have large external networks. Those networks are used to build strong external networks that allow open source companies to:

- Increase the rate of innovation

- Release joint solutions

- Deliver more value to their customers 


\section{Example Text}

Talend expands global footprint with opening of U.S. headquarters and key executive hires.

Source: http://www.talend.com/press/opening-us.php

\subsubsection{Factor 3: Gain insight into open source}

This factor has a factor loading of 3.012 and accounts for $5.5 \%$ of the total variation in the data. Based on the included keywords, this factor has been titled "Gain insight into open source".

\section{Keywords}

The following keywords are correlated with factor 3 .

\begin{tabular}{|l|c|}
\hline Keyword & Correlation to factor \\
\hline innovation at lower cost & 0.8866 \\
\hline insight open source & 0.7786 \\
\hline innovation at a fraction of the cost & 0.6418 \\
\hline developer interest & 0.5536 \\
\hline deliver more value & 0.4621 \\
\hline Investors understand open source & 0.4054 \\
\hline
\end{tabular}




\section{Narrative}

Open source companies reduce customer costs through insight into open source development models and attracting investors who understand open source. Through this deep understanding of open source communities, the companies are able to better utilize the open source assets.

\section{Example Text}

INGRES CEO NAMES OPEN SOURCE AS THE NECESSARY ALTERNATIVE Roger Burkhardt to Discuss the Innovation and Cost Effectiveness of Open Source at Jefferies 2nd Annual Technology Conference.

Burkhardt will address the conference on the history of Ingres and its emergence as a leader and provider of enterprise open source software, which Burkhardt refers to as a "necessary alternative" to any organization looking for a faster time to innovation and dramatically lower costs.

Source: http://www.ingres.com/about/press/08-0910-iefferies.php

GroundWork was one of only five companies to receive the prestigious Under the Radar Innovation Award based on its robust technology solutions, market opportunity and unique value proposition. It competed against seven other companies in the "Companies to Watch" category, winning based on three 
criteria: the business problem the companies solves, the company's unique value proposition and its unfair advantage in the market.

A leader in open source-based IT management solutions, GroundWork provides an open source platform that enables enterprises to effectively monitor their network and application infrastructures at a fraction of the cost of commercial software alternatives.

Source:

http://www.groundworkopensource.com/news/pr/pr 112204 innovation.html

\subsubsection{Factor 4: Test customer buy-in}

This factor has a factor loading of 2.576 and accounts for $4.6 \%$ of the total variation in the data. Based on the included keywords, this factor has been titled "Test customer buy-in".

\section{Keywords}

The following keywords are correlated with factor 4 .

\begin{tabular}{|l|c|}
\hline Keyword & Correlation to factor \\
\hline agreement & 0.7283 \\
\hline business model & 0.6935 \\
\hline
\end{tabular}




\begin{tabular}{|l|c|}
\hline immediately availab & 0.6084 \\
\hline industry analysis & 0.5538 \\
\hline development center & 0.4517 \\
\hline
\end{tabular}

\section{Narrative}

Open source companies must test their potential customer's buy-in to the open source business model. This is done through analysis of the industry and customers as well as the release of easily packaged trial or open source versions of the products. Reaching agreement or understanding with customers, partners and investors is critical to the success of the business.

\section{Example Text}

The agreement grew out of multiple joint customer opportunities driven by strong demand for Pentaho's commercial open source BI capabilities combined with Unisys ability to deliver enterprise-ready solutions that take advantage of open source as well as closed source software.

Source:

http://www.pentaho.com/news/releases/20080923 pentaho and unisys strike $\mathrm{g}$ lobal reseller agreement.php 
Asay was chosen for his sought-after industry analysis and insight through his widely read "The Open Road" blog, where he covers the business and politics of open source. Asay sits on the board of the Open Source Initiative (OSI), is an advisor on a number of boards for open source companies and is the founder and organizer of the Open Source Business Conference (OSBC). The magazine also credited Matt as being instrumental in Alfresco's move to the GNU GPL license, which has increased adoption of Alfresco's software.

Source: http://www.alfresco.com/media/releases/2008/02/matt-asay/

The Astaro Security Gateway version 7 is available immediately. Customers can download the software appliance directly from www.astaro.com. It will also ship with any one of Astaro's full range of hardware appliances.

Source:

http://www.astaro.com/newsroom/press releases/astaro rolls out version 7 of its award winning security gateway utm product

\subsubsection{Factor 5: Raise the bar}

This factor has a factor loading of 2.439 and accounts for $4.4 \%$ of the total variation in the data. Based on the included keywords, this factor has been titled "Raise the bar". 


\section{Keywords}

The following keywords are correlated with factor 5.

\begin{tabular}{|l|c|}
\hline Keyword & Correlation to factor \\
\hline exceed goals & 0.9409 \\
\hline global expansion & 0.9100 \\
\hline launch solution & 0.4119 \\
\hline partner program & 0.4098 \\
\hline
\end{tabular}

\section{Narrative}

Open source companies demonstrate a drive to not just improve, but continuously improve. The setting of new goals and exceeding those goals on a global stage is enabled in large part by a global network of partners and customers.

\section{Example Text}

Alfresco Closes Landmark Financial Year 2007 - Alfresco grows customer bookings by $320 \%$ and community members to 45,000 .

Alfresco broke through the following milestones:

- Surpassed the one million software download mark

- Grew community membership to in excess of 45,000 members 
- Grew customer bookings by over $320 \%$ year-on-year with more than 400 enterprise accounts

- Announced significant OEM partnerships - including a major deal with publishing giant Quark

- Exceeded 30,000 active deployments of Alfresco worldwide

- Won significant new WCM clients in first year of product shipping

- Secured $\$ 9$ million Series $C$ round of financing led by SAP Ventures

Source: http://www.alfresco.com/media/releases/2008/04/fy-2007/

\subsubsection{Factor 6: Provide customers with ability}

This factor has a factor loading of 2.164 and accounts for $3.9 \%$ of the total variation in the data. Based on the included keywords, this factor has been titled "Provide customers with ability to integrate and reuse".

\section{Keywords}

The following keywords are correlated with factor 6 .

\begin{tabular}{|l|c|}
\hline Keyword & Correlation to factor \\
\hline mashup & 0.8730 \\
\hline powerful capabilities & 0.8319 \\
\hline reduce costs & 0.5800 \\
\hline
\end{tabular}


development center

0.4742

\section{Narrative}

Open source companies provide their customers with enhanced ability to integrate and reuse the technology components of the product. Open source companies see this as a key attribute to lowering the cost for customers. Reuse may come in the form of product integration or simple component extraction and reuse.

\section{Example Text}

ProcessMaker and KnowledgeTree deliver open source mashup to radically simplify document-based processes for small businesses.

Combination of Colosa's ProcessMaker open source BPM - workflow with KnowledgeTree's document management software delivers powerful integrated tool to small businesses.

Source: http://www.knowledgetree.com/press/processmaker-knowledgetreebpm-workflow-document-management 


\subsubsection{Factor 7: Release dual license}

This factor has a factor loading of 1.949 and accounts for $3.5 \%$ of the total variation in the data. Based on the included keywords, this factor has been titled "Release dual license".

\section{Keywords}

The following keywords are correlated with factor 7 .

\begin{tabular}{|l|c|}
\hline Keyword & Correlation to factor \\
\hline launch product & 0.8669 \\
\hline launch solution & 0.8324 \\
\hline community edition & 0.5327 \\
\hline
\end{tabular}

\section{Narrative}

Open source companies release commercial and open source product versions.

The commercial version typically includes support, some form of guarantee or modified license; where as the open source version is provided as-is under an open source license.

\section{Example Text}

EnGarde Linux platform combines open source tools for unprecedented security 
Community version of Guardian Digital's award-winning platform provides a robust introduction to network server security.

Source: http://www.guardiandigital.com/company/press/2007/engardecommunity.html

Guardian Digital Internet Productivity Suite is currently available through www.guardiandigital.com and numerous distribution channels. Pricing begins at $\$ 1895$ and includes a license for up to 25 users. All products include comprehensive installation and configuration support for the first year. Registered customers also receive an annual subscription to the Guardian Digital Secure Network for proactive system and security software maintenance.

Internet Productivity Suite is also available in pre-configured turnkey rackmount Internet server appliances, the Guardian Digital Linux Lockbox, configured to address space-saving considerations at co-location facilities, ISPs and ASPs.

Source: http://www.guardiandigital.com/company/press/2003/IPS.html 


\subsubsection{Factor 8: Attract open source investors}

This factor has a factor loading of 1.897 and accounts for $3.4 \%$ of the total variation in the data. Based on the included keywords, this factor has been titled "Attract open source investors".

\section{Keywords}

The following keywords are correlated with factor 8.

\begin{tabular}{|l|c|}
\hline Keyword & Correlation to factor \\
\hline Funding & 0.7687 \\
\hline Investors understand open source & 0.6387 \\
\hline
\end{tabular}

\section{Narrative}

Open source companies see attracting investors who understand open source and open source development models as key to successful funding rounds. Understanding of the open source business model allows investors to trust executive execution in the non-traditional paradigm while aiding the company with access to funding and networks best suited to open source.

\section{Example Text}

Openbravo CEO, Manel Sarasa, said: "This group of high calibre investors is a great fit for Openbravo's aims, combining technology and international expertise and strong networks. Their financing and support will propel the company to the 
next stage of growth accelerating the roll-out of our software around the globe and reinforce our leadership position in open source ERP. As a result, our Board of Directors has been significantly strengthened and we are looking forward to working with our investors."

Commenting on the investment, GIMV's Steven Coppens said: "We expect that Openbravo's open source software business model will be the next breakthrough for the ERP market. Open source offers companies that never had access to truly integrated business systems an opportunity to improve their operations while reducing costs. Openbravo's excellent management team has demonstrated strong execution capabilities, strategic vision and proven software development expertise. We are confident Openbravo will become a successful investment."

Source: $\underline{\text { http://www.openbravo.com/about-us/press-room/news/openbravo- }}$ secures-12m.php

\subsubsection{Factor 9: Enable end-user integration}

This factor has a factor loading of 1.620 and accounts for $2.9 \%$ of the total variation in the data. Based on the included keywords, this factor has been titled "Enable end-user integration". 


\section{Keywords}

The following keywords are correlated with factor 9 .

\begin{tabular}{|l|c|}
\hline Keyword & Correlation to factor \\
\hline integration & 0.6415 \\
\hline SOA & 0.6341 \\
\hline demonstrate & 0.6187 \\
\hline
\end{tabular}

\section{Narrative}

Open source companies provide customers with the ability to integrate their product with other systems; often demonstrating this ability in the form of code samples. Integration of this type is usually described at a product level of integration. Some companies provide products that are designed to ease the effort to integrate various software products.

\section{Example Text}

go-mobile Announces SugarCRM and KnowledgeTree Integration Product for Sugar Exchange

go-mobile ZuckerDocs Provides Integration Between Leading CRM and Document Management Applications. ZuckerDocs Version 2 immediately Available on SugarExchange. 
Source: http://www.knowledgetree.com/press/zuckerdocs-knowledgetree-

sugarcrm-integration

October 19, 2007: CorraTech Kicks Off Open Source Integration Project, Takes an SOA Approach.

CorraTech has started an open source project called OpenSuite under the new GPL 3 license dedicated to the integration of open source applications.

Source: http://www.corratech.com/open-source/news-events-28.html

\subsubsection{Factor 10: Provide support}

This factor has a factor loading of 1.462 and accounts for $2.7 \%$ of the total variation in the data. Based on the included keywords, this factor has been titled "Provide support".

\section{Keywords}

The following keywords are correlated with factor 10.

\begin{tabular}{|l|c|}
\hline Keyword & Correlation to factor \\
\hline standard base & 0.5624 \\
\hline partner & 0.5220 \\
\hline
\end{tabular}




\begin{tabular}{|l|c|}
\hline training & 0.4424 \\
\hline Support for technolog & 0.4180 \\
\hline
\end{tabular}

\section{Narrative}

Open source companies provide support through a number of activities:

- Adopting standards to increase the compatibility of the product and supporting a range of technology platforms

- Attracting partner networks to provide local support to customers

- Providing training to both partners and customers

\section{Example Text}

CollabNet and ReleaseTEAM partner to deliver Software Development Solutions ReleaseTEAM, the configuration management specialists, and CollabNet (www.collab.net) today announced a partnership to help software development teams maximize productivity and cost-savings through increased efficiency across distributed teams. CollabNet is the leading provider of solutions for distributed software development and the company behind Subversion®, the world's best Software Configuration Management tool. Through this agreement, ReleaseTEAM will provide its expert SDLC and best-in-breed consulting services to CollabNet customers, where the companies will jointly support Subversion as the new industry standard for Software Configuration Management (SCM). 
Source: http://www.collab.net/news/press/2008/releaseteam-partnership.html

\subsubsection{Factor 11: Allow users to test solutions}

This factor has a factor loading of 1.303 and accounts for $2.4 \%$ of the total variation in the data. Based on the included keywords, this factor has been titled "Allow users to test solutions".

\section{Keywords}

The following keywords are correlated with factor 11.

\begin{tabular}{|l|c|}
\hline Keyword & Correlation to factor \\
\hline user driven & 0.8618 \\
\hline test drive & 0.5294 \\
\hline
\end{tabular}

\section{Narrative}

Open source companies take their cues from users - enabling them to try solutions before they buy and provide feedback on the experience and feature sets of the product. This may be enabled through a separate open source community and project or a concerted effort of the company itself. This same opportunity is extended to partners. 


\section{Example Text}

Do you want to take a quick test drive of OpenCms to get an impression of its great features?

Source: http://www.alkacon.com/en/news/oldnews $688 . h t m l$

Blade.org is committed to guiding the development and innovation around blade technology. The organization enables BladeCenter ecosystem partners to test and interoperate their products on IBM's BladeCenter.

Source: http://www.virtualiron.com/News-and-Events/News-

Releases/index.php?prld=76

\subsubsection{Factor 12: Partner with trusted parties}

This factor has a factor loading of 1.231 and accounts for $2.2 \%$ of the total variation in the data. Based on the included keywords, this factor has been titled "Partner with trusted parties".

\section{Keywords}

The following keywords are correlated with factor 12. 


\begin{tabular}{|l|c|}
\hline accelerate adoption & 0.8371 \\
\hline partner trusted provider & 0.6821 \\
\hline
\end{tabular}

\section{Narrative}

Open source companies accelerate adoption by partnering with trusted providers and integrators. By partnering with trusted providers, open source companies gain credibility and access to customers.

\section{Example Text}

"Ohloh is the trusted provider of development metrics on thousands of open source projects," said Scott Collison, CEO of Ohloh. "By offering our metrics directly through the CollabNet platform, we bring advanced project information to their users so they know what is happening with their projects and how they stack up against other open source projects."

Source: http://www.collab.net/news/press/2007/ohloh.html

\subsubsection{Factor 13: Provide local support}

This factor has a factor loading of 1.116 and accounts for $2.03 \%$ of the total variation in the data. Based on the included keywords, this factor has been titled "Provide local support". 


\section{Keywords}

The following keywords are correlated with factor 13.

\begin{tabular}{|l|c|}
\hline Keyword & Correlation to factor \\
\hline regional expansion & 0.5805 \\
\hline Subscription & 0.5547 \\
\hline
\end{tabular}

\section{Narrative}

One of the ways that open source companies expand globally is through the attraction of local partners to provide localized support to customers in the region.

\section{Example Text}

Pentaho Continues Rapid Expansion in Europe.

"Pentaho now has more than 20 European-based Systems Integrator (SI) partners to provide professional services for the Pentaho Open BI Suite"

Source:

http://www.pentaho.com/news/releases/20080623 pentaho continues rapid ex pansion in europe.php 


\subsubsection{Factor 14: Reduce the cost of ownership}

This factor has a factor loading of 1.067 and accounts for $1.9 \%$ of the total variation in the data. Based on the included keywords, this factor has been titled "Reduce the cost of ownership".

\section{Keywords}

The following keywords are correlated with factor 14 .

\begin{tabular}{|l|c|}
\hline Keyword & Correlation to factor \\
\hline Grow & 0.5233 \\
\hline deliver more value & 0.4911 \\
\hline lower cost ownership & 0.4757 \\
\hline
\end{tabular}

\section{Narrative}

Open source companies see a path to growth through increasing value to customers and lowering their total cost of ownership. The total cost of ownership includes purchase as well as operational and maintenance costs associated with the software.

\section{Example Text}

Throughout the first half of 2007 , Pentaho has seen strong growth in both direct and indirect sales. End-user organizations are recognizing the value of Pentaho's subscription services to provide a proven, low risk alternative to proprietary $\mathrm{BI}$ 
solutions at a far lower total cost of ownership. Value Added Resellers (VARs) and Original Equipment Manufacturers continue to partner with Pentaho to add embeddable reporting, analysis, dashboards, data integration, data mining, or $\mathrm{BI}$ platform capabilities to their applications.

"We've continued to grow our business and our organization globally during the first half of 2007," said Richard Daley, CEO of Pentaho Corporation. "Now, with the appointment of Matt Vitale, we're expanding our executive leadership team to help drive the next major phase of Pentaho's global expansion."

Source:

http://www.pentaho.com/news/releases/20070629 pentaho appoints matt vital $\underline{\mathrm{e} \text { as executive vice president of worldwide sales.php }}$ 


\section{DISCUSSION OF RESULTS}

This chapter is organized into six sections. The first section describes the competitive actions carried out by open source companies and how those actions relate to the existing Ferrier categories. The second section discusses the resources, processes and values required in an open source company. The third section provides suggestions to executives of companies that compete with open source companies. The fourth section provides suggestions to executives of open source companies. The fifth section discusses the suitability of the research method. The sixth section is a summary.

\subsection{Key findings}

Table 4 shows that the review of the open source literature contributed to our understanding of three competitive action categories described by Ferrier (2001): (i) pricing; (ii) new product; and (iii) capacity.

Table 4 also shows that examining the news releases of the sample companies contributed to our knowledge of two of Ferrier's competitive action categories: (i) pricing; and (ii) service. Table 4 also identifies four actions that do not fit into Ferrier's categories. 
Table 4: Contribution of new insights for Ferrier's categories

\begin{tabular}{|l|c|c|}
\hline Ferrier Category & $\begin{array}{l}\text { Did open source literature } \\
\text { contribute new insights? }\end{array}$ & $\begin{array}{l}\text { Did empirical results } \\
\text { contribute new insights over } \\
\text { open source literature? }\end{array}$ \\
\hline Pricing & Yes & Yes \\
\hline Marketing & No & No \\
\hline New product & Yes & No \\
\hline Capacity & Yes & No \\
\hline Service & No & Yes \\
\hline Signaling & No & No \\
\hline $\begin{array}{l}\text { Number of actions identified } \\
\text { that do not fit }\end{array}$ & 0 & 4 \\
\hline
\end{tabular}

Table 5 relates Ferrier's categories and new categories developed by the researcher, to the researcher's interpretation of the results of the factor analysis.

The four competitive actions identified in the results of the empirical analysis which do not fit clearly in Ferrier's categories are: (i) attract executives and investors; (ii) pull marketing; (iii) improve company overall effectiveness; and (iv) global leadership.

Table 5: Open source competitive actions and related factors

\begin{tabular}{|l|c|}
\hline Category & Related Factors \\
\hline Pricing & - Factor 7: Release dual licenses \\
& - Factor 14: Reduce the cost of ownership \\
\hline Marketing & - N/A \\
\hline New product & - N/A \\
\hline Capacity & - Factor 10: Provide support \\
\hline Service & - Factor 13: Provide local support \\
\hline Signaling & - Factor 2: Attract senior executives \\
\hline Attract senior executives and & - Factor 3: Gain insight into open source \\
investors & - Factor 8: Attract open source investors \\
& - Factor 12: Partner with trusted parties \\
\hline Pull marketing & - Factor 11: Allow users to test solutions \\
\hline
\end{tabular}




\begin{tabular}{|l|l|}
\hline & $\begin{array}{l}\text { Factor 9: Enable end-users integration } \\
\text { - Factor 6: Provide customers with ability to integrate } \\
\text { and reuse }\end{array}$ \\
\hline Improve effectiveness & - Factor 5: Raise the bar \\
\hline Global leadership & - Factor 1: Expand value \\
\hline
\end{tabular}

Table 5 shows that of the 14 factors, four correspond to Ferrier's categorization of competitive action and ten factors are grouped into four new categories. The four factors that correspond to Ferrier's categories have a cumulative variance of $10.17 \%$. The ten factors that have been categorized into the four new categories have a cumulative variance of $48.94 \%$; showing that the news releases of the studied companies place a heavier emphasis on competitive actions that are not described by Ferrier's (2001) categorization.

Figure 1 illustrates the findings of the factors discussed in sections 4.4 .1 to 4.4.14. This figure shows the relationship of the focal company to other parties, the actions taken, and the outcomes or products that are derived as a result of the actions undertaken by the focal company. 
Figure 1: Representation of results

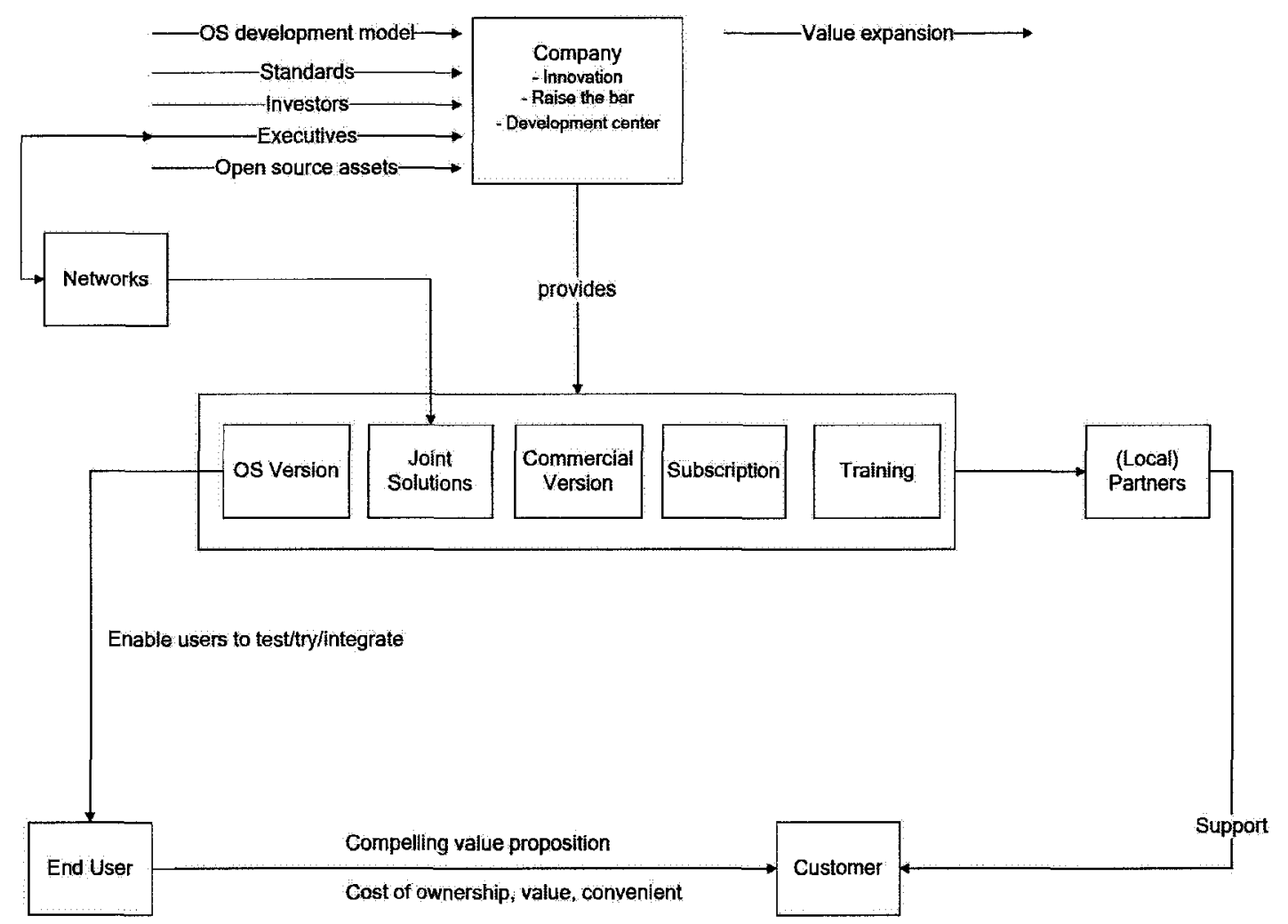

The diagrammatic representation of the factors was useful in synthesizing and understanding what was being described by the factors extracted from information in the news releases.

First, companies in the sample act to draw resources from outside the company. This includes adoption of open source development models, use of open source assets, adoptions of standards, and attraction of investors who understand open 
source. The result of these actions is: (i) build external networks; (ii) raise the bar for goals and (iii) increase the rate of innovation.

Secondly, the external networks built allow the companies to release a greater range of products through joint solutions and increase service offerings by using partners to offer localized support.

Thirdly, the studied companies provide open source and commercial versions of products; create joint solutions with partners and offer support and training to both customers and partners. Providing these services is seen as key to customer value: (i) increasing innovation; (ii) lowering total cost of ownership; and (iii) and providing powerful capabilities and reuse potential. Local partners are seen as key to accelerating adoption.

Finally, companies in the sample draw a distinction between customers and endusers. Customers pay for the product and services previously described, endusers do not pay and are given the opportunity to try the products - most often in the product's open source version. 


\subsubsection{Pricing actions}

Ferrier (2001) defines pricing actions as the increasing or lowering of the price of a product or service sold to a customer. This could include offering a rebate or discount on the sale price of the product.

The open source literature elaborates on Ferrier's definition of pricing by identifying:

- Price at zero: An extreme form of discount pricing, an option that Ferrier had not considered

- Offer dual licenses: A form of pricing that provides two distinct pricing options available to all customers

The empirical results also include the dual licensing option (Factor 7). However, the results point out that the focus of news releases is on the total cost of ownership, not pricing (Factor 14). The total cost of ownership is the operational and maintenance costs of the product, which includes the acquisition cost.

\subsubsection{New product actions}

Ferrier (2001) defines marketing actions as the creation and distribution of advertisements or promotions as part of a campaign. 
The open source literature elaborates on Ferrier's definition of new product by identifying:

- Support an open source project to commoditize a competitors' offering

- Assemble new programs from open source assets

- Create proprietary applications on top of open source stacks

The assembly of new programs and the creation of proprietary applications on top of an open source stack are consistent with Ferrier's launch of new products to the market. The support of an open source project is however a deviation from Ferrier. There is no specific product launch or announcement by the company, the company is also not charging for the open source project. The empirical study of company news releases did not identify any additional details for new product actions.

\subsubsection{Capacity actions}

Ferrier (2001) defines capacity actions as the increase of manufacturing or service capacity or output. The open source literature identifies a unique way for open source companies to increase capacity: the use of open source assets to release a wider range of software products than their proprietary competitors

The empirical study did not identify any additional details for capacity actions. 


\subsubsection{Service actions}

Ferrier (2001) defines service actions as the introduction, launch, roll-out or unveiling of a product.

The open source literature did not reveal additional service actions.

The empirical results show that open source companies provide services in the forms of:

- Factor 10: Provide support

- Factor 13: Provide local support

Ferrier assumes that services are provided by the company; whereas open source companies rely on both internal resources and external partners to provide support and services to customers.

Ferrier (2001) also assumed that service actions were the launch of new service offerings; whereas open source companies take a continuous view of service provisioning. Instead of launching new service offerings; open source companies expand the availability of the service offerings, particularly support through the building of regional networks and continued adoption of standards. More importantly, this change shows open source companies taking actions to ensure there is a strong reliance and dependability in service and support throughout the 
life of the product. This may be a competitive response to proprietary companies attacking the level of support of open source products. In proprietary software, the companies provide support as a part of the purchase price or recurring license; however open source projects have no such guarantee. This requires that support be evident and available throughout the life of the open source product.

\subsubsection{New actions identified in results of factor analysis}

Ferrier (2001) assumes that competitive actions are externally directed towards a rival using internal assets. The new competitive actions identified in the results of the factor analysis suggest that open source companies also act to attract key human and financial resources (e.g., executives and investors who understand open source). These actions are not directed towards a rival as assumed by Ferrier. These actions add capacity, launch products, provide services, and lower ownership costs for its customers.

\subsubsection{Attract executives and investors}

Four factors suggest that open source companies act to attract executives and investors:

- Factor 2: Attract senior executives

- Factor 3: Gain insight into open source

- Factor 8: Attract open source investors 
- Factor 12: Partner with trusted parties

This competitive action seeks to attract the talent to build networks. Those networks take advantage of open source assets, reach customers, speed adoption, increase innovation, and provide support.

\subsubsection{Pull marketing}

Four factors suggest that open source companies act to create an environment where their offers would be pulled:

- Factor 4: Test customer buy-in

- Factor 11: Allow users to test solutions

- Factor 9: Enable end-users to integrate

- Factor 6: Provide customers with ability to integrate and reuse

Ferrier (2001) assumes that competitive actions are aimed at market share of paying customers; the empirical results show a dual view of customers: (i) those who pay; and (ii) end-users who do not pay but try and validate product concepts. In addition, Ferrier's description of competitive actions does not include enablement of customer/users (in this case enabling them to try/integrate). 
This finding illustrates that open source companies use pull marketing models rather than push marketing models. Open source companies enable free use of assets. This free use drives the demand for their market offers as well as complementary market offers. Open source companies use this pull marketing approach instead of pull marketing approaches such as marketing campaigns and traditional advertisement.

\subsubsection{Increase effectiveness}

One factor suggests that open source companies compete by increasing overall operational effectiveness:

- Factor 5: Raise the bar

Neither Ferrier (2001) nor the open source researchers considered the drive to increase operational effectiveness as a competitive action. Actions of open source companies found in the empirical study show a new class of actions that are designed to increase company capability to compete and not just designed to increase market share. By constantly setting and exceeding goals and focusing on global expansion from day one; open source companies demonstrate a view of the market place that differs from proprietary companies. 


\subsubsection{Global leadership}

The category of global leadership is the fourth new category of competitive actions identified by this study. This category was derived from the following factor:

- Factor 1: Expand value

When utilizing open source assets driven by a global community, focus of an open source company is immediately set to a global marketplace as opposed to the immediate geographic area. For an open source company the focus on value expansion is centered on the global expansion and reach of their product offering. This is manifested in the drive for global expansion, platform leadership, and removing adoption barriers.

This competitive action does not target a rival or lever a specific internal or external resource. Instead, the primary focus of this category is the removal of barriers; both for the open source company and the customer.

\subsubsection{Discussion of factor grouping into new actions}

The grouping of factors into new competitive action categories not covered by Ferrier's (2001) categorization; was completed using the following reasoning. 
Factors 2, 3, 8 and 12 have been grouped into attract senior executives and investors and not capacity. Ferrier defined capacity as the direct addition of manufacturing or output capacity; whereas open source companies focus on growth through external networks of the senior executives and investors.

Factors 4, 6, 9 and 11 have been grouped into pull marketing and not into marketing as Ferrier defined marketing as a push based approach utilizing campaigns and advertising. Open source companies have taken a very different approach, and are instead attempting to pull customers to themselves through customer enablement.

Factor 5 stands alone as raise the bar. Factor 1 stands alone as global leadership. Conceivably these factors could be combined. However, they have been left separate as Factor 5 or raising the bar is focused internally; whereas Factor 1 and achieving global leadership is outwardly focused.

\subsection{Resources, processes and values}

Christensen and Raynor (2003) define a company's capabilities as a set of three factors: (i) resources; (ii) processes; and (iii) values. Resources are people, equipment, technology, product designs, brands, information, cash and relationships with suppliers, distributors and customers. They are usually people or things that can be bought and sold, hired and fired, deprecated or built. 
Processes are the patterns of interaction, coordination, communication and decision making though which a company transforms the inputs of resources (the work of people, equipment, technology, product designs, brands, information, energy and cash) into products and services of greater worth. Values are the standards by which employees make prioritization decisions. Resources and processes are generally enabling, while values define the constraints.

The actions found in the empirical analysis of news releases require specific resources, processes and values (RPV) in order to succeed. Table 6 provides a summary of resources, processes and values that are required for an open source company to carry out the actions identified in the study.

Table 6: RPV requirements to support open source competitive actions

\begin{tabular}{|c|c|c|c|}
\hline Category & Resources & Processes & Values \\
\hline Pricing & $\begin{array}{l}\text { Open source } \\
\text { assets }\end{array}$ & $\begin{array}{ll}- & \text { Community } \\
\text { relationship } \\
\text { Development } \\
\text { model } \\
\text { Feedback loops } \\
\text { with end-users } \\
\end{array}$ & \\
\hline Service & & & $\begin{array}{l}\text { Forgoing internal } \\
\text { revenue in favor } \\
\text { of network growth }\end{array}$ \\
\hline $\begin{array}{l}\text { Attract senior } \\
\text { executives and } \\
\text { investors }\end{array}$ & & $\begin{array}{l}\text { Recruitment } \\
\text { process to vet } \\
\text { open source } \\
\text { capabilities and } \\
\text { understanding } \\
\end{array}$ & $\begin{array}{l}\text { Prioritize open } \\
\text { source } \\
\text { understanding } \\
\text { over success } \\
\text { track record } \\
\end{array}$ \\
\hline Pull marketing & & $\begin{array}{l}\text { Sales and } \\
\text { marketing } \\
\text { process }\end{array}$ & $\begin{array}{l}\text { Customer } \\
\text { enablement }\end{array}$ \\
\hline $\begin{array}{l}\text { Improve } \\
\text { effectiveness }\end{array}$ & & $\begin{array}{l}\text { - } \\
\text { Reward or } \\
\text { recognition }\end{array}$ & \\
\hline
\end{tabular}




\begin{tabular}{|l|l|l|l|}
\hline & & system & \\
\hline Global leadership & & $\begin{array}{l}\text { Evaluation of } \\
\text { comparative } \\
\text { value }\end{array}$ & \\
\hline
\end{tabular}

Table 6 shows that open source companies differ from traditional companies requirements of RPV's most greatly in process and values. Resource requirements are remarkably similar. The following sections discuss each of the three aspects in more detail.

\subsubsection{Resources}

Open source companies rely on OSS to generate revenue. Like traditional software companies, open source companies require cash, staff, and relationships. Where they set themselves apart from traditional software companies is the process and values embedded in the company. These specialized process and values allow open source companies to take advantage of the open source assets and define how they interact with partners, customers and end-users.

\subsubsection{Processes}

Making use of open source assets and working with the open source community requires companies to develop processes to work with the community and external assets. As discussed in the literature, the company must ensure they respect the community norms and strike a balance in the give and take 
relationship with the open source community. Legal aspects are also at play. The company must ensure they respect the open source licenses. The open source code may also be the intellectual property of others and added by an open source contributor illegally. Validation of code ownership may also be of greater concern for an open source company.

Another process that may set open source companies apart from traditional companies is the interaction with end-users and not just customers. Being able to gather feedback and input from end-users and not just paying customers may require different tactics. The consideration of end-users has an impact on the sales and marketing team. While their focus is on the acquisition of customers; they must also consider that a portion of their paying customers will come through the conversion of end-users to paying customers.

Executive recruitment and attracting investors is not unique to open source; however, companies in the sample placed a heavy emphasis on finding executives and investors who understand the intricacies of open source. The vetting of such specific knowledge may require a modification to the processes involved.

Recognition and reward in open source companies may take on a different form than traditional companies. While recognition of traditional ideas such as 
process improvements and profit success are still at play; open source companies need to recognize and reward achievements that may not demonstrate an immediate or direct monetary return. Such achievements might include fostering relationships with leaders in open source projects or active participation in open source communities.

Companies in the sample placed emphasis on becoming the leading alternative to the competing proprietary offering. This was done by delivering greater value to customers. As discussed by Bonaccorsi and Rossi (2003), the complete elimination of the proprietary competitor is unlikely; therefore to ensure their direction will provide value, the open source company must institute a means for truthful and realistic appraisal of their offering's value relative to the proprietary offering.

\subsubsection{Values}

Open source companies must value community contribution. A parasitic relationship with the community may damage relationships with the community, making it more difficult for the company to influence the direction of the open source project.

Open source companies carry out actions to create external networks around them in order to expand product adoption. An open source company must forgo 
potentials for immediate revenue by providing all services themselves and instead attract those trusted and regional partners that will provide them with a stronger global presence in the long term.

When attracting executives or investors, previous track records of business success are hard to ignore (Christensen \& Raynor, 2003). Standing true to the need for executives and investors who understand open source can be difficult when faced with choices that seem to have the "right stuff".

Finally, the switch to pull marketing is contingent on the belief that the dual licensing option is a good choice, end-users are valuable resources and value is provided to customers through enablement.

\subsection{Suggestions for executives that compete with open source}

Open source companies focus on actions such as: (i) the attraction of senior executives and investors; (ii) a pull based marketing approach; (iii) a focus on constantly setting new goals - both operational and strategic; and exceeding those goals; and (iv) an out of the gate focus on global leadership and expansion.

Open source companies deemphasize competing in terms of traditional actions such as push marketing, capacity and new product. 


\subsection{Suggestions for executives of open source companies}

This study has revealed a repertoire of 14 actions that are available to open source companies. Ten of those actions are unique to open source, meaning they do not correspond to traditional views of competition.

\subsection{Suitability of approach}

The use of the Microsoft Live search engine to extract the keyword frequencies from the news releases of company websites faced three challenges:

1. Many sites included keywords in navigation elements of the site and not the content

2. Standard copy employed by specific companies in their news releases confused some results during initial runs

3. Restricting the search to news releases was dependant on the structure of each individual site

Rather than a single solution, or workaround, the focusing and targeting of the Live Search engine to the correct content relied on a site by site design of the search query to account for these factors. The advanced search options used to address these were the intitle, inbody, site and the use of exact match exclusions. 
Many company sites follow URL patterns for news releases or common titling patterns of news releases. This allowed for a case-by-case construction of queries such as "site:www.alfresco.com/news" or "site:www.alfresco.com intitle:news" to allow restriction of searches to news releases.

To address the navigational content or the standard text in the news releases, each site had to be examined for conflicts with keywords. When found, exclusion queries were developed to eliminate these false positives from the results or when not possible the keywords were eliminated from the sample.

If neither of the above approaches was possible, the company was eliminated from the sample.

\subsection{Summary}

The results of the empirical study suggest the following.

1. In open source, pricing includes more than pricing and discounting of products. Open source introduces extreme ranges in pricing; i.e., pricing the product at zero; and introduces a two-option pricing structure in the form of dual licenses. 
2. Ferrier's definition of service actions is modified in the context of open source. This modification is required to account for service actions being performed by external companies and the continuous and on-going nature of those service actions when compared to Ferrier's definition of service actions.

3. New action categories have been identified that add to the existing Ferrier categories. These categories are:

a. Attract senior executives, investors and their networks

b. Movement from push marketing tactics to pull marketing tactics

c. Increasing effectiveness of competitive actions

4. The empirical study did not reveal any additional insights for marketing, new product, capacity and signaling actions.

5. One new action category found is distinctly different from the existing Ferrier categories: global leadership. 


\section{CONCLUSIONS, LIMITATIONS, AND FUTURE RESEARCH}

This chapter is organized into three sections. The first section presents the conclusions of this research. The second section provides the limitations of this research. The third section provides opportunities for future research.

\subsection{Conclusions}

Previous studies (Ferrier, 2001) on competitive actions have examined externally directed actions enabled by internal assets, and specific studies on competitive dynamics in open source have identified six competitive actions available to open source companies. By examining news releases of open source companies, this is the first study to examine the competitive actions of open source companies.

This research led to the following conclusions:

1. The distribution of factors across existing and new actions shows that open source companies undertake different competitive actions than traditional companies and place a heavier emphasis on those actions than traditional competitive actions.

2. Open source companies employ a pull driven marketing approach; attracting customers through enablement. This is the opposite end of the spectrum from the push marketing examined in previous competitive actions research. 
3. The method employed in the research: the use of search engine APl's and the publicly available news releases of the companies was successfully utilized.

\subsection{Limitations}

This research has at least three limitations.

The first limitation is that this research used publicly available information from company websites. Company staff was not interviewed so motivations for the competitive actions found were not identified. Furthermore, the reasons given in the news releases for actions may have been purposefully or unintentionally misrepresented on the part of the company.

The second limitation is that there is no comprehensive database of companies that rely on open source projects for their revenue. Additional companies may have demonstrated additional competitive actions.

Third, results rely on researcher's interpretation of what the factors mean. 


\subsection{Opportunities for future research}

This study identifies two opportunities for future research:

1. Examine how subjective the results are as determined by the:

a. choice of search engine used to determine keyword frequencies

b. choice of initial set of keywords

2. Examine the sequence of actions taken by companies using the date stamps on the news releases

3. Examine how companies compete to control the production of open source assets and ensure how they can continue to use that open source asset

4. Examine the actions taken by open source companies to convert endusers to paying customers

5. Incorporate additional categories from Derfus (2008) and Boyd and Bresser (2008) and demonstrate how this would modify the results of this study. Upon first inspection the new categories of range and format are specific to the retail sector and would not have influenced the results of this study. The categories of direct channel, merger and acquisition, geographic growth and legal however are not as clearly delineated and further study is required. 


\section{REFERENCES}

Alam, R. 2006. Open source software projects, market offers and competitive advantage. Masters Thesis, Telecommunications and Technology Management, Carleton University, Ottawa, Ontario.

Aslett, M. 2007. Open source funding: the complete picture http://www.businessreviewonline.com/os/archives/2007/02/open source fun 2.h tml (Accessed 1 July 2007)

Basdeo, K., Smith, K., Grimm, C., Rindova, V. and Derfus, P. 2006. The impact of market actions on firm reputation. Strategic Management Journal, 27(12): 1205-1219.

Brandenburger, A. and Nalebuff, B. 1997. Co-Opetition : A revolution mindset that combines competition and cooperation: the game theory strategy that's changing the game of business. Doubleday Business. New York.

Bonnaccorsi, A., Giannangeli, S. and Rossi, C. 2006. Entry strategies under competing standards: hybrid business models in the open source software industry. Management Science, 52(7): 1085-1098.

Bonaccorsi, A., C. Rossi. 2003. Why open source software can succeed? Research Policy, 32: 1243-1258.

Bonaccorsi, A. and Rossi, C. 2004. Comparing motivations of individual programmers and companies to take part in the open source movement. from community to business. 
http://opensource.mit.edu/papers/bnaccorsirossimotivationlong.pdf. Accessed 30 June 2007.

Boulding, W. and Christen, M. 2001. Idea-first-mover disadvantage. Harvard Business Review, 79(9): 20-21.

Boyd, J. and Bresser, R. 2008. Performance implications of delayed competitive responses: evidence from the U.S. retail industry. Strategic Management Journal, 29(10): 1077-1096.

Casadesus-Masanell, R. and Ghemawat P. 2006. Dynamic mixed duopoly: a model motivated by Linux vs. Windows. Management Science, 52(7): 10721084.

Charitou, C. D. and Markides, C. C. 2003. Responses to disruptive strategic innovation. MIT Sloan Management Review, 45: 55-63.

Cottrell, T. and G Sick, G. 2001. First mover (dis)advantages and real options. Journal of Applied Corporate Finance, 14(2):41-51.

Christensen, C. and Raynor, M. 2003. The innovator's solution. Harvard Business School Publishing Corporation. Boston.

Dahlander, L. and Magnusson, M. 2005. Relationships between open source software companies and communities: Observations from Nordic companies. Res. Policy 34(4) 481-493. 
Dahlander, L. 2004. Appropriating returns from open innovation processes: a multiple case study of small firms in open source software, Working Paper, Chalmers University of Technology.

Darlington, R. 2007. Factor analysis.

http://www.psych.cornell.edu/Darlington/factor.htm. Accessed September 20, 2007.

Das, T. and Teng, B. 2000. Instabilities of strategic alliances: an internal tension perspective. Organization Science, 11:77-101.

Dean, S. 2008. Record numbers for open source venture capital funding. http://ostatic.com/158788-blog/record-numbers-for-open-source-venture-capitalfunding. Accessed April 29, 2008.

Derfus, P., Maggitti, $P_{\text {, }}$ Grimm, C. and Smith, K. 2008. The red queen effect: competitive actions and firm performance. Academy of Management Journal, 51(1): 61-80.

Economides, N. and Katsamakas, E. 2006. Two-sided competition of proprietary vs. open source technology platforms and the implications for the software industry. Management Science, 52(7): 1057-1071.

Ferrier, W. and Lyon, D. 2004. Competitive repertoire simplicity and firm performance: the moderating role of top management team heterogeneity. Managerial \& Decision Economics, 25(6): 317-327. 
Ferrier, W and Lee, H. 2002. Strategic aggressiveness, variation, and surprise: how the sequential pattern of competitive rivalry influences stock market returns. Journal of Managerial Issues, 14(2): 162 - 180.

Ferrier, W., Mac Fhionnlaoich, C., Smith, K. and Grimm, C. 2002. The impact of performance distress on aggressive competitive behavior: a reconciliation of conflicting views. Managerial and Decision Economics, 23: $301-316$.

Ferrier, W. 2001. Navigating the competitive landscape: the drivers and consequences of competitive aggressiveness. Academy of Management Journal, 44: 858-877.

Ferrier, W., Smith K.G. and Grimm C. M. 1999. The role of competitive action in market share erosion and industry dethronement: a study of industry leaders and challengers. Academy of Management Journal, 42: 372-388.

Gans, J.S. and Stern, S. 2003. The product market and the market for "ideas": commercialization strategies for technology entrepreneurs. Research Policy. 32(2): 333-350.

Gimeno, J. 1999. Reciprocal threats in multimarket rivalry: staking out 'spheres of influence' in the US airline industry. Strategic Management Journal, 20: 101128.

Gimeno, J. and Woo, C. Y. 1999. Multimarket contact, economies of scope, and company performance. Academy of Management Journal, 43: 329-359. 
Grand, S., von Krogh, G., Leonard, D. and Swap, W. 2004. Resource allocation beyond company boundaries: A multi-level model for open source innovation. Long Range Planning 37(6) 591-610.

Haveman, H. A. and Nonnemaker, L. 2000. Competition in multiple geographic markets: the impact on growth and market entry. Administrative Science Quarterly, 45: 232-267.

Henkel, J. 2004. Patterns of free revealing - balancing code sharing and protection in commercial open source software development. http://opensource.mit.edu/papers/henkel2.pdf. Accessed February 10, 2007.

Hicks, D., Libaers, D. and Porter, A. 2006. Identification of technology commercialization strategies of high-tech small companies. Small Business Research Summary, 289.

Ketchen, D., Snow, C. and Hoover, V. 2004. Research on competitive dynamics: Recent accomplishments and future challenges. Journal of Management, 30(6): 779-804.

Khanna, T., Gulati, R. and Nohria, N. 2000. The economic modeling of strategy process: clean models and dirty hands. Strategic Management Journal, 21: 781790.

Koenig, J. 2004. Seven open source business strategies for competitive advantage. http://www.riseforth.com/pdfs/Seven-Open-Source-BusinessStrategies-JCK.pdf. Accessed February 12, 2007. 
Lerner, J. and Tirole, J. 2000. The simple economics of open source. Working paper no 7600, National Bureau of Economic Research, Cambridge, MA.

Lieberman, M. B. and Montgomery, D. B. 1988. 1st-mover advantages, Strategic Management Journal, 9: 41-58.

Mustonen, M. 2003. Copyleft: The economics of Linux and other open source software. Discussion Paper 493, Department of Economics, University of Helsinki, Helsinki, Finland.

Mustonen, M. 2005. When does a company support substitute open source programming? J. Economic Management Strategy 14(1) 121-139.

Nadkarni, S. and Narayanan, K. 2007. Strategic schemas, strategic flexibility, and firm performance: the moderating role of industry clockspeed. Strategic Management Journal, 28(3): 243-270.

Pal, N. and Madanmohan. 2002. Competing on open source: strategies and practices. http://opensource.mit.edu/papers/madanmohan.pdf. Accessed February 12, 2007.

Raymond, E.S. 1999. The cathedral and the bazaar: musings on Linux and open source by an accidental revolutionary. Sebastopol: O'Reilly.

von Krogh, G. and von Hippel, E. 2006. The promise of research on open source software. Management Science, 52(7): 975-983. 
Williams, S. 2007. Gaining and losing market share and returns: a competitive dynamics model. Journal of Strategic Marketing, 15: 139-148.

Young, G., Smith, K. G., Grimm, C. M. and Simon, D. 2000. Multimarket contact and resource dissimilarity: A competitive dynamics perspective. Journal of Management, 26: 1217-1236.

Young, G., Smith, K. and Grimm, C. 1996. Austrian and industrial organization perspectives on firm-level competitive activity and performance. Organization Science, 7(3): 243-254. 


\section{APPENDIX}

\section{Appendix A: List of companies in the sample}

\begin{tabular}{|l|l|}
\hline Company & Website \\
\hline Alfresco & www.alfresco.com \\
\hline Alkacon & www.alkacon.com \\
\hline Astaro & www.astaro.com \\
\hline CleverSafe & www.cleversafe.com \\
\hline CollabNet & www.collab.net \\
\hline Compiere & www.compiere.com \\
\hline Corratech & www.corratech.com \\
\hline db40 & www.db4o.com \\
\hline Digium & www.digium.com \\
\hline EnterpriseDB & www.enterprisedb.com \\
\hline ez & ez.no \\
\hline Funambol & www.funambol.com \\
\hline Greenplum & www.greenplum.com \\
\hline GroundWork & www.groundworkopensource.com \\
\hline Hyperic & www.ingres.com \\
\hline Ingres & www.ingres.com \\
\hline JasperSoft & www.knowledgetree.com \\
\hline Knowledge Tree & www.knowledgetree.com \\
\hline MuleSource & www.mulesource.com \\
\hline MySQL & www.mysgl.com \\
\hline Nuxeo & www.nuxeo.com \\
\hline Pentaho & www.pentaho.com \\
\hline RedHat & www.redhat.com \\
\hline rPath & www.rpath.com \\
\hline SnapLogic & www.snaplogic.com \\
\hline SpringSource & www.springsource.com \\
\hline SugarCRM & www.sugarcrm.com \\
\hline Talend-d & www.talend.com \\
\hline WaveMaker & www.wavemaker.com \\
\hline ws02 & wso2.com \\
\hline Zenoss & www.zenoss.com \\
\hline Zmanda & www.zmanda.com \\
\hline Virtual Iron & www.virtualiron.com \\
\hline XWiki & www.xwiki.com \\
\hline Intalio & www.intalio.com \\
\hline RadView & www.radview.com \\
\hline & \\
\hline
\end{tabular}




\begin{tabular}{|l|l|}
\hline eRacks & eracks.com \\
\hline OpenLogic & www.openlogic.com \\
\hline SpikeSource & www.spikesource.com \\
\hline Levanta & www.levanta.com \\
\hline Apatar & apatar.com \\
\hline Paragent & www.paragent.com \\
\hline Project Open & www.project-open.com \\
\hline ICEFaces & www.icesoft.com \\
\hline Canonical \& Ubunto & www.ubuntu.com \\
\hline Talend & www.talend.com \\
\hline OpenBravo & www.openbravo.com \\
\hline Open-XChange & www.open-xchange.com \\
\hline Vyatta & www.vyatta.com \\
\hline Six Apart & www.sixapart.com \\
\hline Zimbra & www.zimbra.com \\
\hline Varien & www.varien.com \\
\hline GigaSpaces & www.gigaspaces.com \\
\hline Scalix & www.scalix.com \\
\hline OpenMFG & www.openmfg.com \\
\hline OrangeHRM & www.orangehrm.com \\
\hline Akaza & www.akazaresearch.com \\
\hline CigNex & www.cignex.com \\
\hline LibLime & liblime.com \\
\hline MedSphere & www.medsphere.com \\
\hline JumpBox & www.jumpbox.com \\
\hline TrollTech & trolltech.com \\
\hline SafeSoftware & www.safe.com \\
\hline jitterBit & www.jitterbit.com \\
\hline Emu Software & www.emusoftware.com \\
\hline Aras & www.aras.com \\
\hline TrixBox & www.trixbox.com \\
\hline extJS & extjs.com \\
\hline GuardianDigital & www.guardiandigital.com \\
\hline Exist & www.exist.com \\
\hline rSmart & www.rsmart.com \\
\hline enFold & www.enfoldsystems.com \\
\hline DM Solutions Group & www.dmsolutions.ca \\
\hline 2Bit & 2 bits.com \\
\hline BPO Canada & bpocanada.com \\
\hline LinuxIT & www.linuxit.com \\
\hline Zeroc & www.zeroc.com \\
\hline & \\
\hline
\end{tabular}


Appendix B: List of companies used to identify keywords

\begin{tabular}{|l|l|l|}
\hline Company Name & URL & Date Accessed \\
\hline Alfresco & www.alfresco.com & April 29, 2008 \\
\hline Mule Source & www.mulesource.com & May 3, 2008 \\
\hline Sugar CRM & www.sugarcrm.com & May 6, 2008 \\
\hline Zenoss & www.zenoss.com & May 6, 2008 \\
\hline
\end{tabular}


Appendix C: List of keywords used to examine news releases

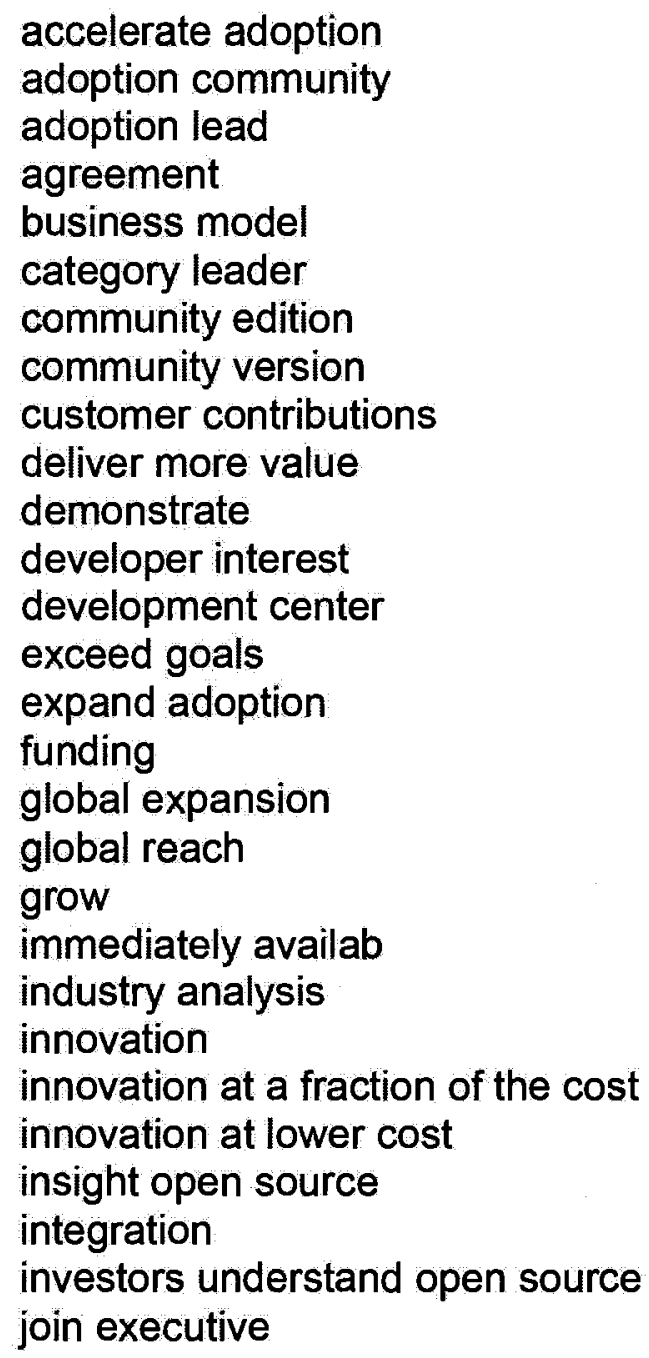

join leaders

joint solution launch product launch solution lead emerging technology lock-in lower cost ownership mashup

new alternative

partner

partner program partner trusted provider powerful capabilities rapid development rapid innovation reduce costs regional expansion reseller

SOA sponsor standard base strength management subscription support for technolog test drive training user driven 
Appendix D: Factors that resulted from analysis of news releases

\begin{tabular}{|l|r|r|r|}
\hline Factor & Eigenvalue & Variance (\%) & $\begin{array}{c}\text { Cumulative } \\
\text { variance (\%) }\end{array}$ \\
\hline 1: Expand value & 7.066 & 12.848 & 12.848 \\
\hline 2: Attract senior executives & 3.620 & 6.582 & 19.430 \\
\hline 3: Gain insight into open source & 3.001 & 5.457 & 24.886 \\
\hline 4: Test customer buy-in & 2.576 & 4.684 & 29.570 \\
\hline 5: Raise the bar & 2.439 & 4.434 & 34.004 \\
\hline 6: Provide customers with ability & 2.164 & 3.935 & 37.939 \\
\hline 7: Release dual license & 1.949 & 3.544 & 41.483 \\
\hline 8: Attract open source investors & 1.897 & 3.450 & 44.933 \\
\hline 9: Enable end-user integration & 1.620 & 2.946 & 47.879 \\
\hline 10: Provide support & 1.462 & 2.658 & 50.537 \\
\hline 11: Allow users to test solutions & 1.303 & 2.369 & 52.906 \\
\hline 12: Partner with trusted providers & 1.231 & 2.239 & 55.146 \\
\hline 13: Offer local support & 1.116 & 2.029 & 57.175 \\
\hline 14: Reduce the cost of ownership & 1.067 & 1.940 & 59.115 \\
\hline
\end{tabular}

